\title{
ヒト口腔各種組織初代培養細胞の動態に関する顕微鏡 映画法ならびにオートラジオグラフィーによる研究
}

第 2 報 口腔各種腫痬細胞について

\author{
曰田篤伸 \\ 東京医科歯科大学歯学部第 1 口腔外科学教室（指導：上野正教授）
}

（昭和47年10月15日受付）

\begin{abstract}
Cinemicrographic and Autoradiographic Studies on the Behaviors of Primary Culture Cells from Human Oral Tissues

II. On the Various Tumor Cells of Oral Region
\end{abstract}

\author{
Tokunobu Usuda \\ The First Department of Oral Surgery, School of Dentistry, Tokyo \\ Medical and Dental University \\ (Chief and Director: Prof. Dr. Tadashi Ueno) \\ (Received on 15, October, 1972)
}

要旨 : 本教室では1965年以来組織培養法を応用しヒト口腔領域の正常ならびに腫瘍組織の動態解明を試み, その成果を発表してきたが，著者はこれらの知見を一層明確にするために，前報において顕微鏡映画法なら びに ${ }^{3} \mathrm{H}-\mathrm{TdR}$ 投与オートラジオグラフィーを応用してヒト口腔上皮細胞の形態, 動き, 増殖の様相の経日的 推移について検索を行なった。今回は多種多様にわたる口腔腫瘍の動態解析のために前報と同様の方法を用 いて検索を行なった。

研究材料は, 東京医科歯科大学歯学部付属病院第 1 口腔外科を受診した患者のうち, 良性腫瘍 13 例, 覀性腫 瘍17例の試験切除片および手術摘出物より得た。培養法は直接カバーグラス法により, 培養液は Eagle MEM ニッサンを用い, $37^{\circ} \mathrm{C}$ の $\mathrm{CO}_{2}$ 培養器で培養した。顕微鏡映画撮影は培養後 20 時間目から行ない, 同時に その同型培養体に対し ${ }^{3} \mathrm{H}-\mathrm{TdR}(0.5 \mu \mathrm{Ci} / \mathrm{ml})$ を $1 \mathrm{cc}, 1.5$ 時間投与した後固定し, オートラジオグラフを作 製して DNA 標識指数および分裂指数を計測した。

良性腫瘍由来上皮性細胞は, 一般にシートを形成して遊出し, 細胞間結合を保った 比較的均一な細胞集団 より成っており, 細胞の動き, 増殖は緩慢な例が多かった。シートの形, 細胞形態などは各腫腸間, 培養例 によって特徴的所見を認めた。

悪性腫瘍由来細胞は明膫なシートを形成することは少なく, 細胞結合も弱く, 細胞異型性が著明であった。 細胞の動き, 増殖は活発な例が多く, $6 \sim 7$ カ月以上の長期にわたり分裂增殖を 持続する例もあった。細胞 分裂像には多極分裂などが多数見られ，それらは分裂時間が $2 \sim 3$ 時間に延長していた。またオートラジオ グラフィーにより得られた L.I. と M.I. の経日的推移の曲線は, ほぼ相似の関係が認められ, 本実験におけ る腫锡細胞において DNA 合成を行なった細胞のほとんどが分裂を行なっていくものと考えられた。また, L.I., M.I. および顕微鏡映画法により測定された分裂時間の計測値とから求めた DNA 合成時間および世代 時間の推定值は, それぞれ良性腫場では, 多形性腺腫が前者 11.2 時間, 後者 61.0 時間, 以下同様にエナメル 上皮腫が13.5時間, 115.7 時間であり, 悪性腫瘍では扁平上皮癌が 14.5 時間, 45.6 時間, 腺様霊胞癌が 6.9 時 間，46.6時間，エナメル上皮肉腫が9.2時間，139.8時間であり，各腫瘍間に差異が認められた。 
I . 緒論

II. 研究材料および研究方法

III. 実験結果

1. 顕微鏡映画法による細胞動態の観察
1）良性腫瘍由来細胞

2）悪性腫瘍由来細胞

2. オートラジオグラフィーによる labeling index および mitotic index の経日的推移の観察
1）良性腫瘍由来細胞
2）悪性腫瘍由来細胞

IV. 総括ならびに考按

1. 培養法抒よび培養液

2. 顕微鏡映画法による細胞動態について

3. 細胞分裂像について

4. labeling index, mitotic index の経日的推移と世 代時間（generation time）について

V. 結論

\section{I. 緒 論}

臨床において遭遇する腫瘍病変は 多種多様にわ たり，それぞれの臨床所見，病理組織所見，臨床 細胞学的所見は個々の症例により異なっている。

これら腫瘍の初代培養細胞に 関する研究もいく つかみられているが ${ }^{1-7)}$ ，均一な細胞集団が得難 く，その定量化も困難なために実験動物腫瘍のそ れに較べて，詳細な研究は少ない走-7)。Paul $(1962)^{1)}$, 小浜 $(1967)^{4)}$ ，中川 $(1971)^{8)}$ らの研究 によると, 腫瘍由来初代培養細究は, 正常組織由 来のそれに較べて, 形態, 増殖能および染色体所 見などが異なっていると報告されており，とり わけ悪性腫瘍では著しく変化に富むことが明らか にされた。しかし，これら 培養細胞の形態，動 き，増殖能の経日的推移の 様相は十分には明らか にされておらず6)，著者はこれらの問題解明のた めに，16ミリ微速度顕微鏡映画法と三重水素標識 チミジン $\left({ }^{3} \mathrm{H}\right.$-thymine deoxyribonucleocide, ${ }^{3} \mathrm{H}$ $\mathrm{TdR}$ と略）投与オートラジオグラフィーを併用し て実験し, 口腔腫瘍初代培養細胞の 動態追究を行 なった。

顕微鏡映画法を用いてヒト腫瘍組織由来初代培 養細胞について, 細胞動態の系統的観察を行なっ
ているものは肺癌を用いた Sherwin ら $(1968)^{6)}$ の報告のみであり, 初代培養細胞の形態, 動き, 増殖の様相の経日的推移について 検索した報告は 見当らなかった。

著者は第 1 報9)において口腔上皮細胞に 関する 知見を発表したが，本論文では口腔領域各種腫瘍 細胞についての顕微鏡映画法による観察結果およ びオートラジオグラフィーによる 細胞動態の分析 結果について報告する。

\section{II. 研究材料および研究方法}

培養材料は 東京医科歯科大学歯学部附属病院第 1 口腔外科を受診した患者のうち，良性腫瘍13例， 悪性腫瘍17例の計30症例の試験切除組織片および 手術摘出物より得られた（表 1 )。

その内容は, 良性腫瘍例では多形性腺腫 6 例, 工 ナメル上皮腫 5 例, エナメル上皮線維腫 1 例, 神経

表 1 培養材料

\begin{tabular}{c|c|c|c}
\hline & 試験切除 & 摘出手術 & 計 \\
\hline 良性 腫 瘍 & 3 & 10 & 13 \\
悪性 腫 瘍 & 8 & 9 & 17 \\
\hline 計 & 11 & 19 & 30
\end{tabular}

表 2 良性腫瘍の培養例

\begin{tabular}{c|c}
\hline \hline 組 織 診 & 培養例数 \\
\hline 多 形 性 腺 腫 & 6 \\
エナメル上皮腫 & 5 \\
エナメル上皮線維腫 & 1 \\
神 経 䩗 腫 & 1 \\
\hline 計 & 13
\end{tabular}

表 3 悪性腫瘍の培養例

\begin{tabular}{c|c}
\hline 組 織 診 & 培養例数 \\
\hline 扁 平上皮 癌 & 10 \\
腺 樣 囊 胞 癌 & 3 \\
悪 性 黒 色 腫 & 2 \\
粘 表 皮 癌 & 1 \\
エナメル上皮肉腫 & 1 \\
\hline 計 & 17
\end{tabular}


鞘腫 1 例で，また悪性腫瘍例では扁平上皮癌 10 例， 腺様囊胞癌 3 例, 悪性黒色腫 2 例, 粘表皮癌 1 例 およびェナメル上皮肉腫 1 例であった（表 2,3$) 。$ 壊死巣を形成している癌腫の試験切除に際して は，口内抢よび当該腫瘍部を $3 \%$ 過酸化水素水で 十分洗滌し，さらに生理食塩液にて壊死組織，被 苔物を静かに除去して，できる限り新鮮な腫瘍組 織片の採取に努めた。

採取した組織片は，前報の口腔粘膜上皮の場合 と同様に処理し培養に移した。培養法は直接カバ ーグラス法を採用し，培養液は Eagle MEM 二 ッサンを用いた。

3. 観察法

1） 16 ミリ微速度顕微鏡映画法による 細胞動態 の観察

第 1 報と同様に培養後約 20 時間目以降，倒立位 相差顕微鏡により 細胞遊出を確認したのち，16ミ リカメラに連結された 自動露出微速度顕微鏡映画 撮影装置にて 1 分 1 コマで映画撮影を行ない，腫 瘍細胞の 遊出および増殖の 様相を 記録，観察し た。なお細胞分裂像の見られた培養例については， 映画フィルムより分裂時間を測定した。その際そ れぞれの腫瘍例につき 2 極分裂を行なった 細胞を 原則として20個任意に選定して 分裂時間の測定を 行なった。分裂時間は分裂前期の細胞球形化開始 期から，終期の細胞質分裂直後までを測定した。

2. オートラジオグラフィーによる labeling index と mitotic index の経日的推移の観察

培養開始後 20 時間目以降，前述のごとく映画撮 影を行なうと同時に，比較的安定した増殖を示し
た培養例に対し，経日的に $0.5 \mu \mathrm{Ci} / \mathrm{ml}$ （比放射能 $5.0 \mathrm{Ci} / \mathrm{mM})$ の ${ }^{3} \mathrm{H}-\mathrm{TdR}$ 溶液 $1 \mathrm{cc}$ を 1.5 時間投与 した 1 回標識を行ない，前報と同様にしてオート ラジオグラフを作製し，細胞集団の DNA 標識指 数 (labeling index, L.I. と略) および細胞分裂 指数 (mitotic index, M.I. と略) の経日的推移を 検索した。なお口腔腫瘍培養細胞においては, DNA 標識細胞の分布が遊出細胞帯の 全域にわた ってほぼ均等であったので，L.I. の算定に際して は全域の細胞を対象とし，光学顕微鏡下に任意に 400 500個の細胞を選定して行なった。また M.I. の算定は L.I. の算定を行なった標本の同一部位 について 400 500 個の 細胞について行なった。 これらの測定を行なった培養例について 良性腫瘍 を B，悪性腫瘍をMの記号で表わした（表 4)。

\section{III. 実 験 結 果}

1. 顕微鏡映画法による細胞動態の観察

1）良性腫瘍由来細胞

本項目で観察されたのは多形性腺腫, エナメル 上皮腫，エナメル上皮線維腫，および神経鞘腫の 4 腫瘍であった。これらの細胞の遊出開始は比較 的遅く, 培養後 $2 \sim 4$ 日目からであり細胞の動 き，および増殖はいずれも緩慢な例が多かった。 またそれぞれの組織に特有な細胞形態を維持して 増殖し，比較的長期間，著明な形態的変化は認め られなかった。

i) 多形性腺腫：本腫瘍の遊出は 培養後 $2 \sim 3$ 日目に開始された，上皮性細胞がシートを形成し て母組織の一部から遊出することが多く，そのシ

表 4 L.I. および M.I. の検索症例

\begin{tabular}{|c|c|c|c|c|}
\hline & 症 例 & 性 & 年 齢 & 部位および組織診 \\
\hline \multirow{4}{*}{ 良性腫瘍 } & $\mathrm{B}-1$ & 男 & 53 & 口蓋多形性腺腫 \\
\hline & $B-2$ & 男 & 55 & 口蓋多形性腺腫 \\
\hline & $\mathrm{B}-3$ & 男 & 21 & 下顎 エナメル上皮腫 \\
\hline & $B-4$ & 女 & 24 & 下顎エナメル上皮腫 \\
\hline \multirow{4}{*}{ 悪性腫瘍 } & $M-1$ & 男 & 55 & 下顎歯肉扁平上皮癌 \\
\hline & $\mathrm{M}-2$ & 男 & 49 & 扁平上皮癌の頸部リンパ節転移 \\
\hline & $M-3$ & 女 & 61 & 口底 部腺様 囊胞癌 \\
\hline & $\mathrm{M}-4$ & 男 & 29 & 上顎エナメル上皮肉腫 \\
\hline
\end{tabular}




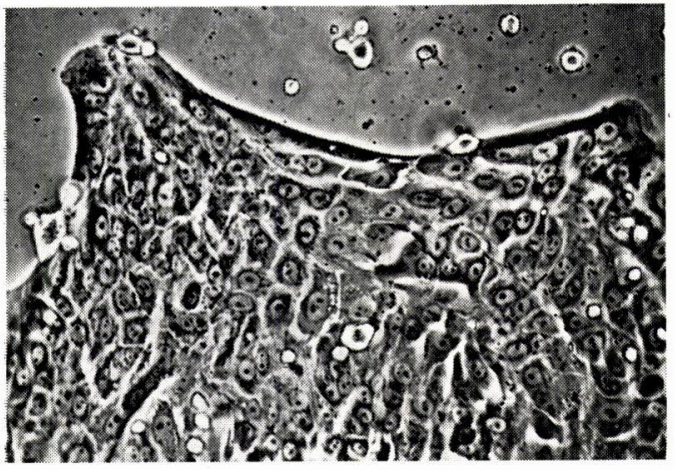

図 1 多形性腺腫由来細胞。培養後 3 日目。類円形 細胞が主体を占めるシートの一部。多角形状 の外形を呈している。(原倍率100倍)。

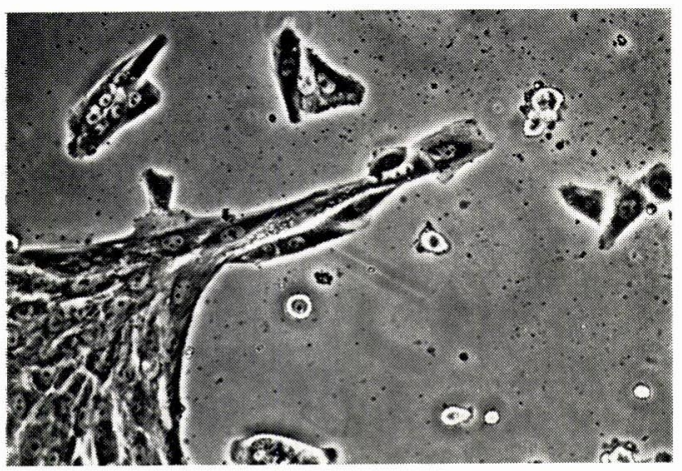

図 2 多到性腺腫由来細胞。培養後 4 日目。紡鍾形 細胞が主体を占めているシートの一部。数個 の遊走した細胞集団では多角形ないし不規則 の細胞形態を示す。(原倍率100倍)。

ートの外形は，ところどころに突出した細胞遊出 の自由縁を有し，多角形を形づくるような外観 を呈していた（図 1)。その部分的に突出したシー トの頂点相当部からは，波動膜がやや伸展して 緩慢な運動がみられたが，他の大部分では辺縁の 細胞が紡錘状に細長く伸びているものが多く，波 動膜はほとんど観察されなかった。また頂点相当 部に紡鍾形細胞が多く在存する場合には, 図 2 の ごとく，そこから細胞集団が棘状に突出している こともあり，また，シートから離れて単一または 数個の細胞集団の存在もみられた。シートの広が る速さは培養例により異なり, 一般には遅く, 培 羪初期には10 20 $/ \mathrm{hr}$ であり，かつ比較的早期に 広がりは停止した。シートの中では細胞は比較的
密に配列しており細胞間吵は不均一であった。シ ートに抢ける細胞形態は，細胞が密に配列してい る小型の類円形細胞と, 細胞質を伸展させた, や や大型の類円形細胞より成る場合 (図 1 ), および 紡鍾形細胞が比較的密に配例している場合（図 2 ) とが観察された。

核は楕円形で比較的均一な形態を示すものが多 く，多核を有する細胞はほとんど見られなかった。 細胞形態は培養日数が経過しても著明に変化す ることは少なく，観察を行なった約 1 力月間では 培養初期の形態を維持する傾向が認められた。

細胞分裂像は遊出直後には少ないが，比較的早 期から観察された。培養10日以降は細胞の動き, 増殖ともに緩慢になる傾向にあった。細胞分裂に 要する時間は平均 $42.3( \pm 5.3)$ 分であった。

ii）エナメル上皮腫：本腫瘍における腫瘍細胞 の遊出は培養後 $2 \sim 4$ 日目に始まった。

シートの外形はほぼ円形を呈しておりり, 遊出後 比較的早期に母組織の 全周にわたって細胞遊出 がみられた（図 3 )。シートの広がる速さは多形

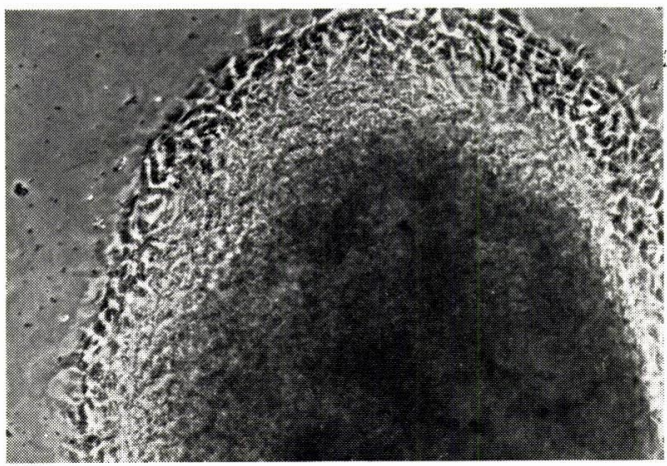

図 3 エナメル上皮腫由来細胞。培養後 4 日目。ほ ぼ円形のシート形成し, 母組織の全周から遊 出している。(原倍率80倍)。

性腺腫より遅く, 培養初期に約 $5 \sim 15 \mu / \mathrm{hr}$ であっ た。シートをはなれて個々に遊走する細胞も少数 見られたが，全体としては細胞間結合が良く保た れていた。またシート内では細胞が重層化し, 細 胞間隙が不鮮明になることもあった。細胞形態を みると，細胞質がよく発達した 細胞が一般に見ら れ，やや紡鍾形に近かったが，扁平上皮様形態を 


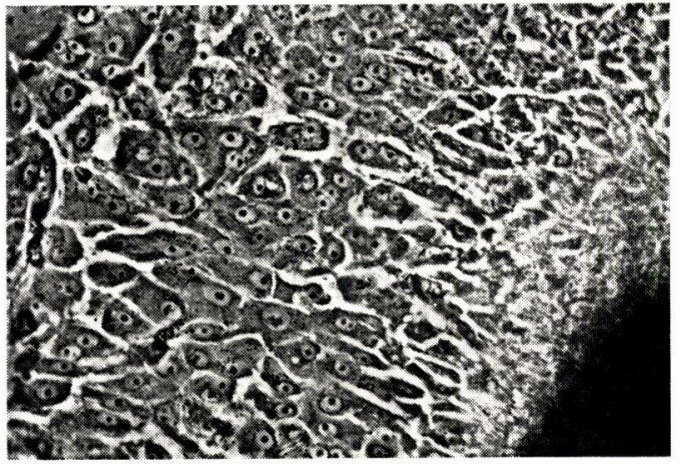

図 4 エナメル上皮腫由来細胞。培養後 6 日目。ほ ぼ均一な紡錘形細胞集団より成る。（原倍率 100倍)。

示していた（図 4)。増殖が比較的活発にみられた 部位では，やや丸みをおびていることもあった。 シート辺縁部の絽胞は扁平化し，大型化すること もあった。細胞質には多数の顆粒がみられ培養経 過とともに，それはさらに増加していった。細胞 の動きは不活発なことが多かったが，シート辺縁 部の細胞は波動膜を伸ばしており，やや活発な運 動がみられた。

核は円形ないし棈円形で，ほぼ均一な形態を示 し，核小体はやや大型のものが $1 \sim 2$ 個明膫に認 められた。

母組織は細胞遊出とともに扁平化し, 形も著明 に変形していくことが多かった。

細胞分裂像は一般に少なく，分裂に要する時間 は平均40.1（土5.1）分であった。

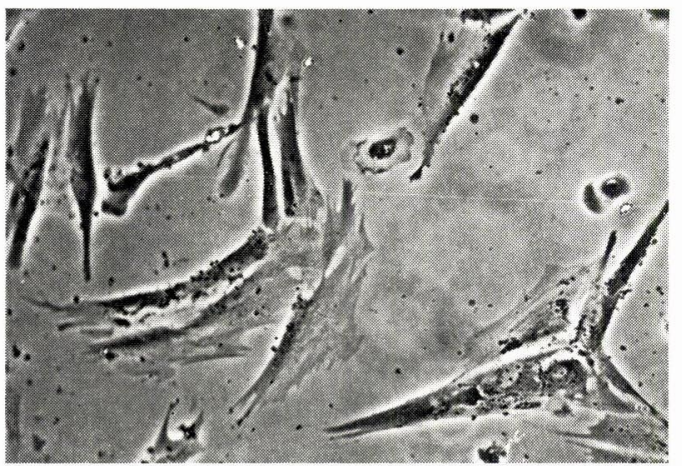

図 5 エナメル上皮線維腫由来細胞。培養後 8 日目。 線維芽性細胞。細胞配列は一定の極性を示さ ず細胞形態は紡鍾形であったが，細胞外形は 凹凸不整である。位相差像。(原倍率100倍)。 iii）エナメル上皮線維腫 : 培養後 $3 \sim 4$ 日目に 線維芽性細胞が遊出してきた（図 5 )。シートは形 成せず，また細胞は母組織に対する極性も示して いなかった。遊出細胞数は少なく，それらの動き は極めて緩慢であった。

細胞形態は紡錘形であったが，正常口腔粘膜由 来の線維芽性細胞のように形態が均一ではなく, 波動膜の辺縁は回凸不整であった。細胞質内の顆 粒はやや増加していたが，核形態はほぼ楕円形を 示し，異型性は軽度であった。核小体は $2 \sim 3$ 個 認めれた。一方細胞分裂像は観察されなかった。

なお培養後 6 日目に一部のものでは上皮性細胞 が原腫瘍組織（図 6 )の上皮性細胞に相応し，その 母組織の一部分からシートを形成して遊出した。 細胞は重層化していたが，エナメル上皮腫由来細 胞に近似していた。これらの細胞はほとんど増殖 を行なわず，動きも極めて緩慢であった。

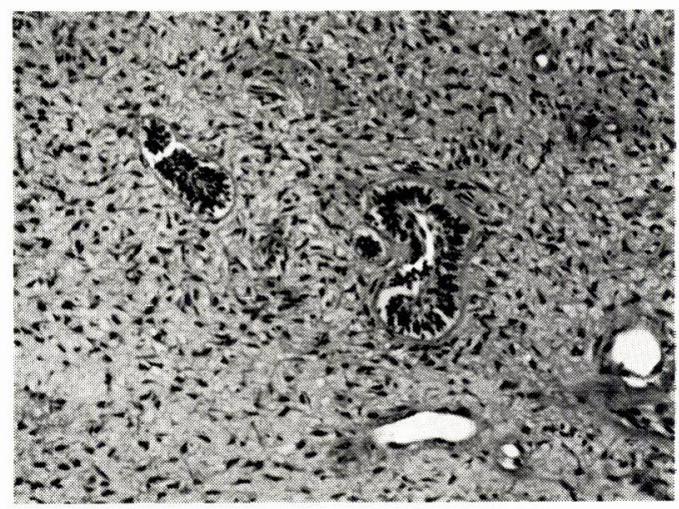

図 6 エナメル上皮線維腫組織切片標本。閒葉性細 胞が主体を占めているが，ほぼ中央には上皮 性細胞の集団がみられる。H-E 染色。（原倍 率100倍)。

iv） 神経鞘腫 : 培養後 2 日目に，3〜 4 本の細 胞質突起を有する細長い細胞が多数遊走してきた （図 7 ）。シートを形成することはなく，細胞質突 起の運動が活発にみられたが，位置移動は少なか った。これらの細胞は小膠細胞（microglia）由来 のものと思われた。突起同士が相互に結合してい る所見も見られたが，ほとんどの細胞は個々に分 離し，自由な運動を行なっていた。また一部では 細胞集団が直線的配列を示していた。 microglia 


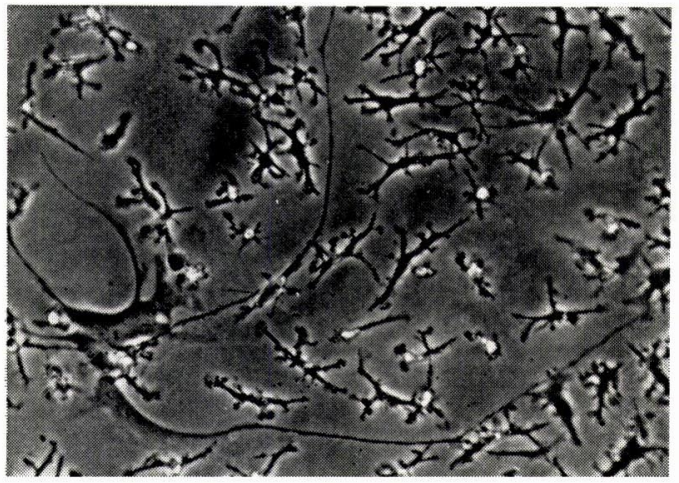

図 7 神経鄘腫由来細胞。培養後 6 日目。多数の小 型の小膠細胞 (microglia) とともに, 長い突 起を有する線維芽性細胞が遊走している。16 ミリ映画フィルムより。(原倍率50倍)。

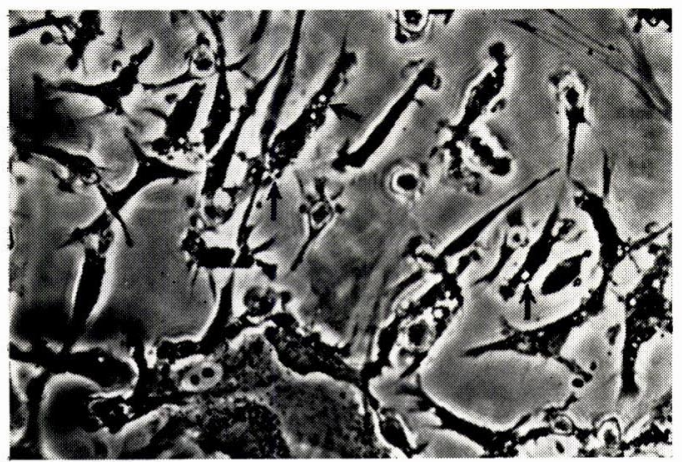

図 8 神経䩗腫由来細胞。培養後 6 日目。小膠細胞 (microglia) は 3〜 4 本の突起を有し, 細長 い形態を示す。 pinocytosis（矢印）が著明に みられた。位相差像。(原倍率200倍)。

の細胞形態は細長いので, 細胞内構造を明瞭に観 察することはできなかったが, 細胞は活発な pinocytosis（細胞の曖飲作用 ${ }^{10)}$ ) 在行なった（図 8 ）。 核は 1 個ずつ認められ， 1 個の核小体を有し ていた。細胞分裂像は観察されなかった。培養後 4 日目頃になると原腫瘍組織像（困 9）の実質細 胞に相当すると思われる非常に長い突起を有する 線維芽性細胞が遊出してきた（図７）。シートを形 成することはなく，細胞の動きは極めて緩慢であ った。長い突起がゆっくり移動するのに伴ない, 細胞形態も自由自在に変化した。またその長い突 起により相互に結合している細胞集団も見られ， さらにそれら細胞の周囲に microglia が附着して いる所見も散見された。細胞分裂像は認められな

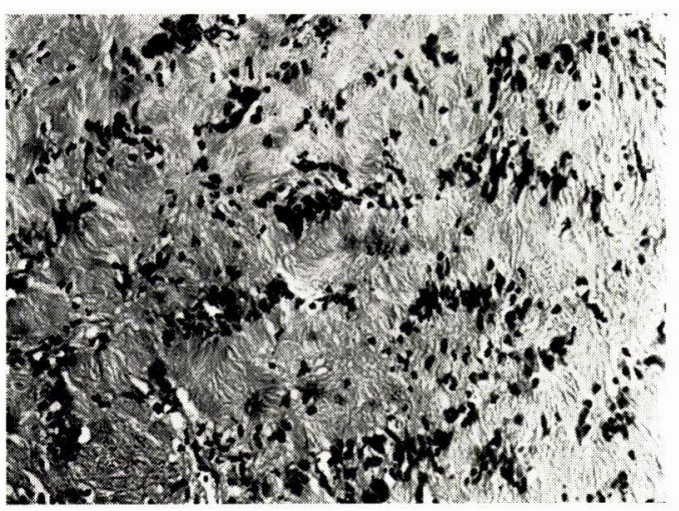

図 9 神経鞘腫組織切片標本。線維芽性細胞より成 り，核が特徴ある柵状配列を示している。 $\mathrm{H}-\mathrm{E}$ 染色。(原倍率100倍)。

かった。

口腔粘膜上皮組織の培養の場合と同様の円形細 胞 ${ }^{9)}$ は培養後 1 日目には多数出現し，とりわけマ クロファージが多数見られた。

2）悪性腫瘍由来細胞

本項目で観察したのは扁平上皮癌, 腺様囊胞癌, 悪性黒色腫，粘表皮癌，およびエナメル上皮肉腫 であった。これら腫瘍からの細胞遊出開始は一般 に培養 $1 \sim 3$ 日後であり，そのらち扁平上皮癌が 最も早かった。腫瘍細胞の動き，および増殖は活 発なものが多かった。また遊出細胞はそれぞれの 腫瘍組織に特徵的な 細胞形態を示しており, 細胞 異型性が著明に認められた。

i）扁平上皮癌：培養下で良好に増殖した場合 には，上皮性細胞の遊出が培養後16時間目に観察 された例もあり，他の腫瘍に比して早期から細胞 遊出が見られた。これら遊出細胞には上皮シート を形成した場合と, 母組織から離れて孤立した細 胞集落を形成した場合とがあった。シート内では 細胞境界が明瞭に認められたものも多かったが, シートの外形は凹凹不整を呈した（図10）。細胞間 結合は弱く, 細胞集団は容易に離散集合をくりか えしており，個々の細胞は活発に不規則な運動を 行ないながら遊出した。培養の経過とともに細胞 が重層していくシートも多数見られた。

細胞形態は培養初期から著明な異型性を示し, 細胞の大小不同性, 多形性が見られた。細胞質内 


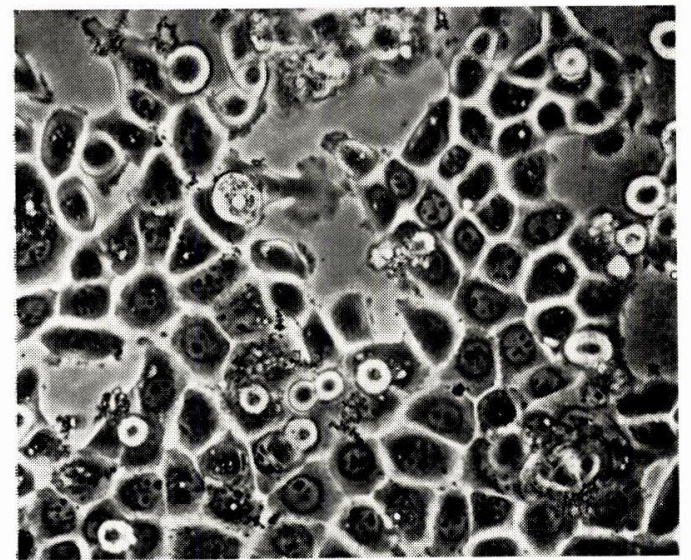

図 10 扁平上皮癌由来細胞。培養後 4 日目シート の外形は凹凸不整を呈し，その中の細胞は 異型性に富んでいる。位相差像。（原倍率 100 倍)。

には種々な顆粒が数多く存在し，それらにも活発 な動きがみられた。

細胞は活発な波動膜運動を行ないながら遊走し ており，その速さは $90 \sim 100 \mu / \mathrm{hr}$ におよぶことも あった。また波動膜を大きく伸展している細胞に は pinocytosis が著明に観察されたが，細胞結合 を行ならとそれは消失した。

核形態も異型性が強く，一般に大型で，核膜は 肥厚し，多核細胞も数多く観察された。核小体 は，その数および形態に変異が著しく，とりわけ 大型のものが多く，癌細胞の特徵を有していた

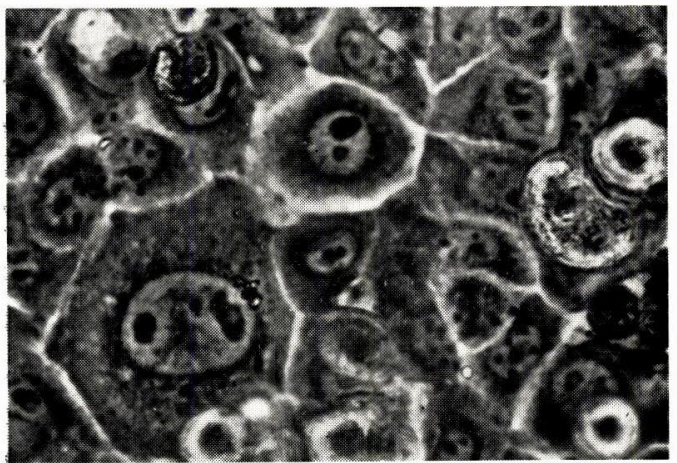

図 11 扁平上皮癌由来細胞。培養後 4 日目。細胞 配列は不規則で，細胞，核，核小体は強い 異型性を示している。位相差像。（原培率 200倍)。
(図11)。

細胞形態は培養経過とともに扁平化し, 大型に なる傾向があり，変性していくものも少なからず 観察された。しかし増殖の旺盛な培養例では，6 〜 7 力月後になっても著明な変性を示さず，初期 の悪性細胞の特徵を有して増殖し，比較的均一な 細胞集団をなしており, 細胞間隙も明瞭であった。 またもとのシートから遠く離れたガラス面に細胞 集落を形成したり，細胞集団が重層化していく所 見もみられた（図 $12 ， 13$ )。

一方線維性細胞が出現する場合は，通常上皮性

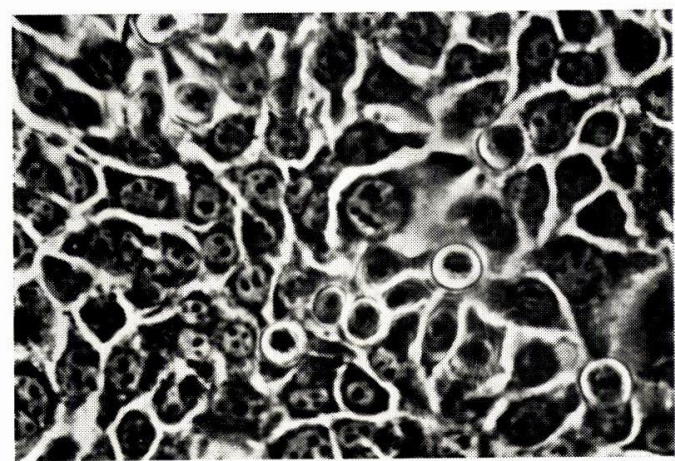

図 12 扁平上皮癌由来細胞。培養後 180 日目。細 胞は集落を形成して増殖し，比較的小型の 均一な細胞集団をなしている。核，核小体 は細胞質に比して大きく異型性著明。細胞 分裂像が多数認められる。位相差像。（原 倍率200倍)。

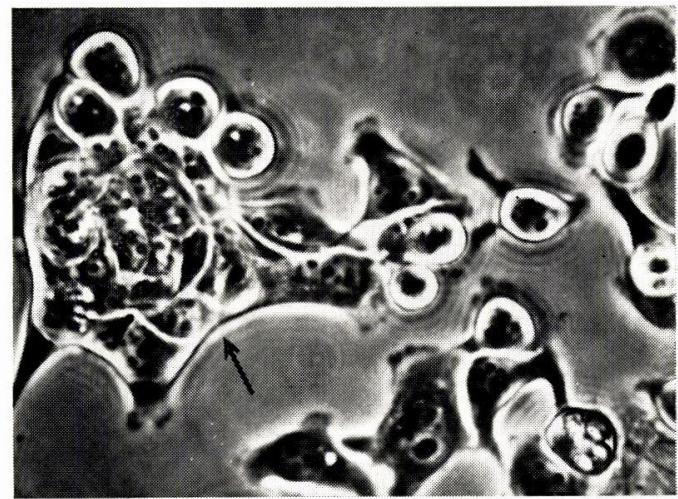

図 13 扁平上皮癌由来細胞。培養後 180 日目。多層 化して増殖する細胞集団 (矢印)。細胞質を あまり伸展していない。位相差像。（原倍率 200倍)。 


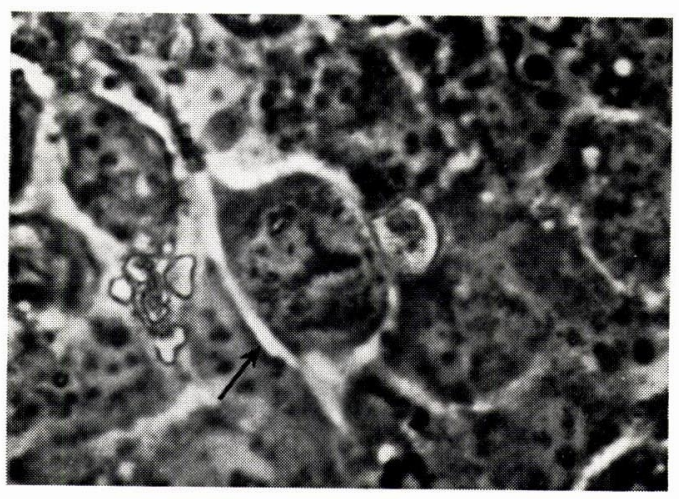

A : 分裂開始直後

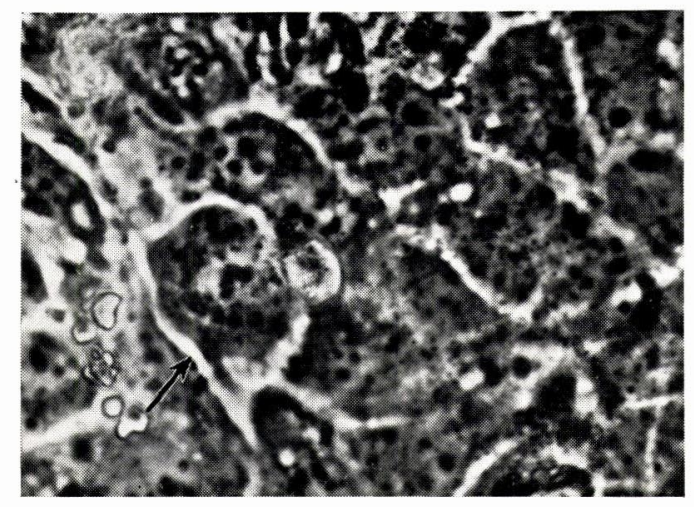

$\mathrm{C}:$ 同60分後

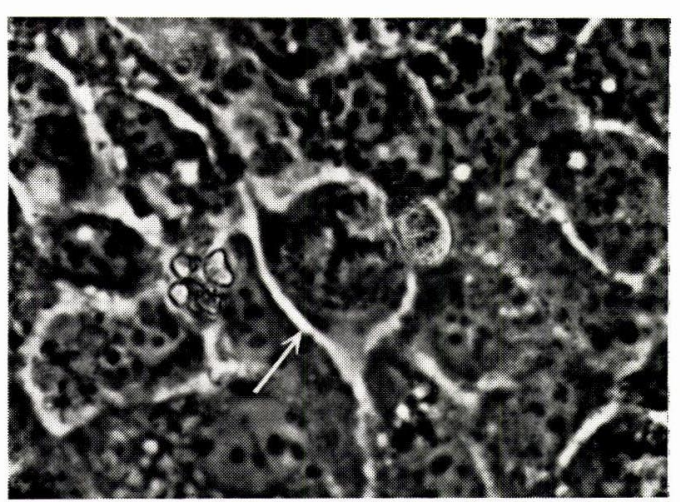

B：同40分後

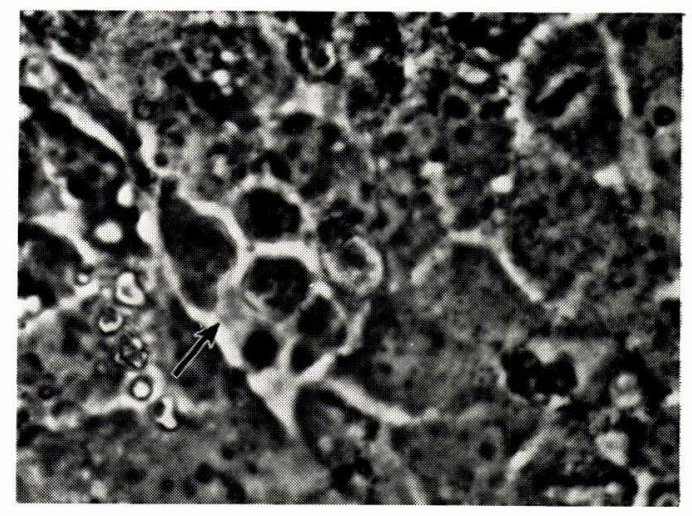

$\mathrm{D} ：$ 同70分後

図 14, A D 扁平上皮癌由来細胞。培養後200日目。三極分裂老行な5細胞（矢印）。 $\mathrm{A} ： \mathrm{~T}$ 字型 の染色体配列が見られる。 B : A から 40 分後に染色体配列はY字型に変化した。 C：Bから20分後に核分裂が行なわれ，それぞれの染色体群は 3 個のV字型在呈し ている。D：Cから10分後に細胞質分裂が行なわれ，ほぼ三等分された。右上方に は二極分裂像がみられる。16ミリ映画フィルムより。(原倍率200倍)。

細胞の増殖が衰える約 2 週間目頃から見られ, 変 性過程にある多核巨細胞をとり囲む所見がしばし ば観察された。しかし上皮性細胞が長期にわたり 増殖を持続した場合には線維芽性細胞が出現して も，その増殖は抑制されていた。

次に細胞分裂像は培養初期から多数観察された が，その中には不等分裂や $3 \sim 4$ 極分裂などの異 常な分裂像が少なからず存在し（図14，A～D）， かっ同一細胞集団の 中に多発する傾向があった。 多極分裂を行なら細胞は分裂中期の像が通常の 2 極分裂のそれに較べて大型であり，かつ染色体の 配列像が多極を呈していたので，分裂前からそれ を識別することが可能であつた。分裂期に至って
分裂停止 (mitotic arrest) する細胞も多数観察さ れ，その多くは数時間後に死滅していった。また 培盖経過を通じて細胞が変性壊死を起こす場合 は，分裂中期付近に扮けるものが大部分であっ た。分裂に要する時間は良性細胞に較べると一般 に延長しており，平均62.2（土24.4）分であっ た。異常な分裂像を示すものでは特に長時間かか り，2〜3 時間におよぶものも少なからず 観察さ れた。しかし20日以上も増殖が良好に持続された 例では比較的均一な細胞集団をなし，かつ安定し た分裂像を示し，分裂の途中で変性に宿いるもの は少なかった。

初代培養一般におけると同様に見出された円形 
細胞は培養初期から認められ，とくに頸部リンパ 節転移病单からの培養例では多数見られた。そ れらは活発な運動を行ない，癌細胞にまつわり つくものが多かった。しかし扁平上皮癌では細胞 間隙に抽て速やかに移動することは少なかっ た。

ii）腺様囊胞癌：細胞の遊出は培養後 $2 \sim 3$ 日 目から見られた。比較的均一な細胞集団をなす培 養例ではシートを形成したが (図15)，異型細胞の 多い例では安定したシートを形成しなかった（図 16)。シートの広がりは緩慢で，多形性腺腫のそ

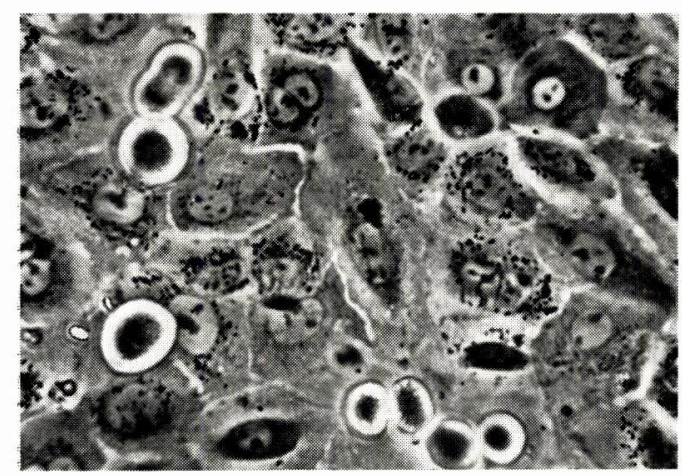

図 15 腺様囊胞癌由来細胞。培養後 8 日目。シー 卜を形成しているが, 細胞配列は不規則で， 核の大小不同性がみられる。核周囲の顆粒 も多い。位相差像。(原倍率200倍)。

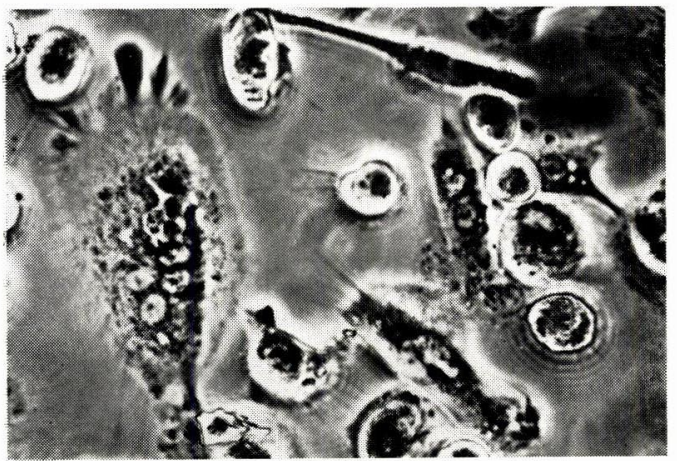

図 16 腺様囊胞癌由来細胞。培養後15日目。シー トを形成せず,細胞の大小不同性は著しく， 多核巨細胞もみられる。位相差像。（原倍 率200倍)。

れに近かった。シートの外形は凹凸不整も見られ たが, 多形性腺腫由来細胞と類似のシートを示す
こともあった。細胞配例は不規則で，同境界は不 鮮明であった。細胞は円形ないし，紡鍾形を呈 し, 細胞質内には多くの顆粒が存在し, 細胞異型 性も強くなっていた。シートから離れて個々に運 動している細胞もあり，それらの細胞からはしば しば細長い細胞質の突起が伸びていた。

核は円形ないし棈円形を呈し，一般に大型化し ており，多核細胞も多かった。このように癌細胞 の特徵を有する培養例のほかに，多形性腺腫由来 細胞と形態的に判別困難なほど異型性の 低い所見 を示す例もあった。培養後期（20 30 日後）にい たっても著明な形態的変化を示すことは少なく, 一方細胞分裂像は全体として少なかったが比較的 長期間観察された。

iii）粘表皮癌：培養後 $2 \sim 3$ 日目に遊出を開始 した。遊出とともにシートを形成したが，その外 形は不規則であった。遊出速度は緩慢で，初期に は10 20 $\mu / \mathrm{hr}$ であった。しかしシートを形成し ていても細胞結合は弱く，離散集合をくりかえす ことが多かった。細胞配列は不規則で敷石状を示 すことは少なかった（図17）。細胞形態は母組織実 質細胞（図 18）のような腺系細胞と類似してい た。細胞の一端からは細長い突起が伸びていた。 細胞の動きは緩慢で，培養日数の経過に伴ない次 第に静止していった。核は小型の類円形を呈して

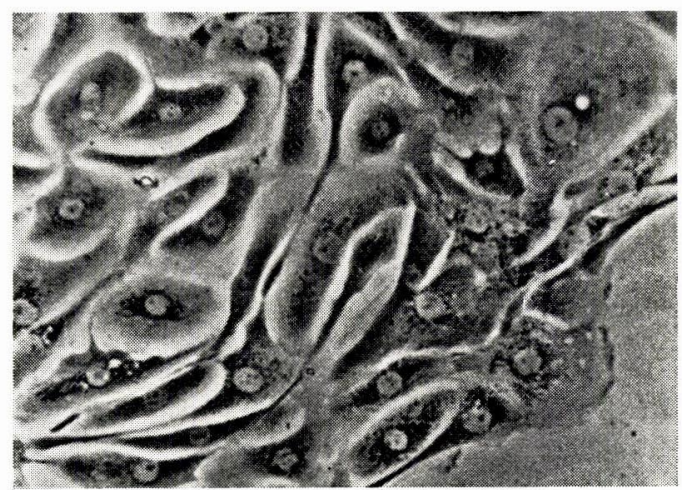

図 17 粘表皮癌由来細胞。培養後 6 日目。シート を形成しているが，細胞配列は不規則で細 胞間結合は弱功た。細胞形態は鋭三角形 様を呈し, その頂点相当部には細長い突起 が見られる。16ミリ映画フィルムより。(原 倍率100倍)。 


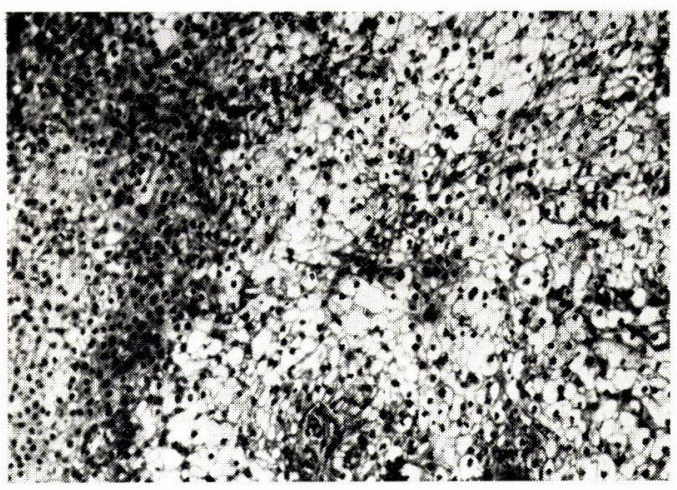

図 18 粘表皮癌組織切片標本。左側の濃染してい る部分は酸好性細胞。右側は粘液産生細胞 で核が小さく細胞質がぬけて見られる。 $\mathrm{H}-\mathrm{E}$ 染色。(原倍率100倍)。

いるのが特徴的で核の周囲には小さな顆粒が多数 認められた。核小体は 1 〜 個存在した。細胞 分裂像はごく少数認められた。

シートの中にみられた円形細胞は細胞間隙を速 やかに移動することがなく，一箇所で活発な運動 をしており 1 数個の細胞の周囲を回転している ことが多かった。

iv）悪性黒色腫：培養後 $3 \sim 4$ 日目に黒いメラ ニン顆粒を多量に含む 腫瘍実質細胞（网19）由来 であることの特に明確な細胞が遊出してきた（図 20)。その遊出様式としてはシートを形成しないで 個々ばらばらに遊出していることが多かつた。細 胞はかなり活発な運動を行なっていたが，位置移

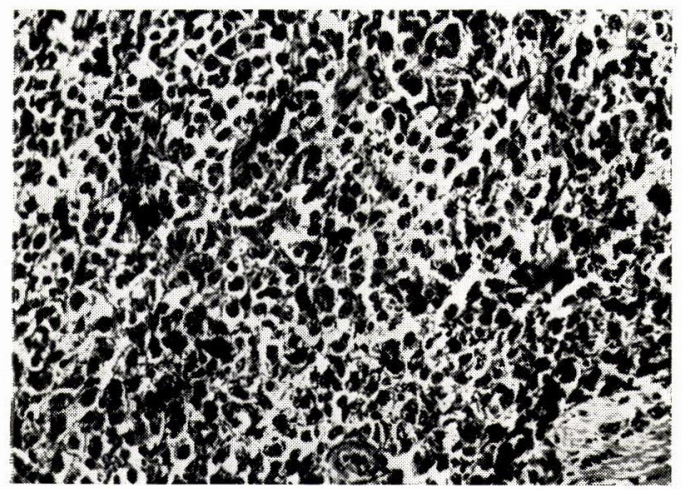

図 19 悪性黒色腫組織切片標本。ほとんどの細胞 が多量のメラニン顆粒を含んでいる。H-E 染色。(原倍率100倍)。

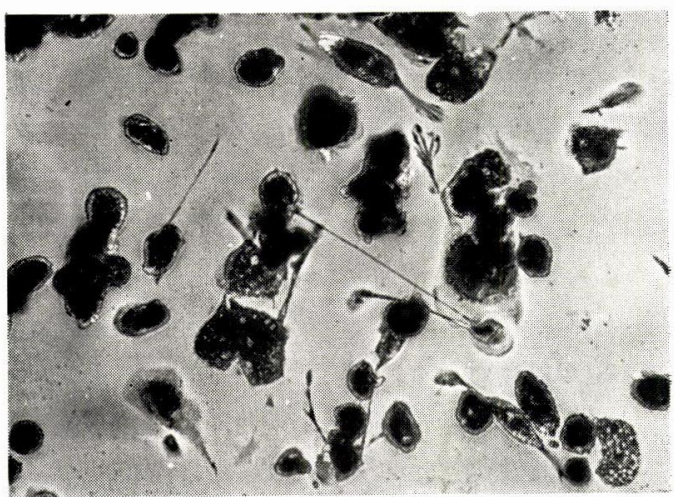

図 20 悪性黒色腫由来細胞。培養後10日目。多量 のメラニン顆粒を含んだ実質細胞が遊走し ている。細手指様を示す細胞質の突起がみ られる。位相差像。(原倍率100倍)。

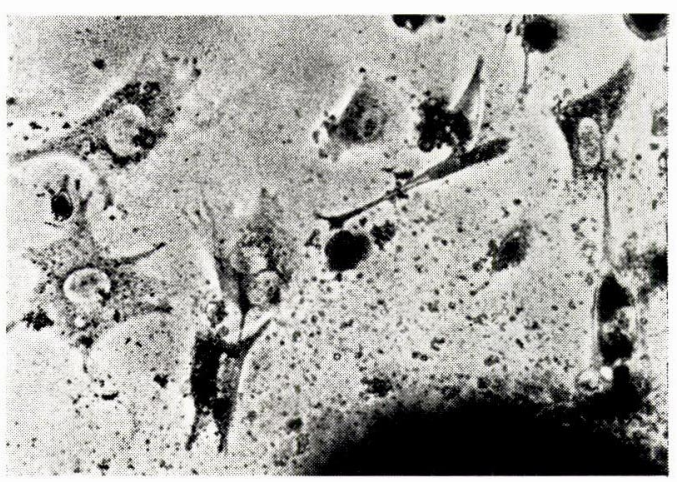

図 21 悪性黒色腫由来細胞。培養後10日目。線維 芽性細胞形態を示寸細胞集団。細胞内のメ ラニン顆粒は比較的少ないがガラス面には 多数散乱している。16ミリ映画フィルムよ り。(原倍率100倍)。

動はあまり見られなかった。細胞形態は上皮性の ものが主体で円形ないし紡錘形のものが多く， そ の際多量のメラニン顆粒のため細胞内構造はほと んど観察できなかった。一方線維芽性細胞形態を 示すものも見られたが (眓21)，その細胞内のメラ ニン顆粒は比較的少なく細胞内構造もかなりはっ きり認められた。波動膜を著明に伸展している細 胞は少なかったが，細手指様の細長い形を示した 細胞質突起が数多く観察された。細胞質内に多量 に認められるメラニン顆粒は，その一部がガラス 面に散乱しており細胞の移動を妨げているよらで あった。 


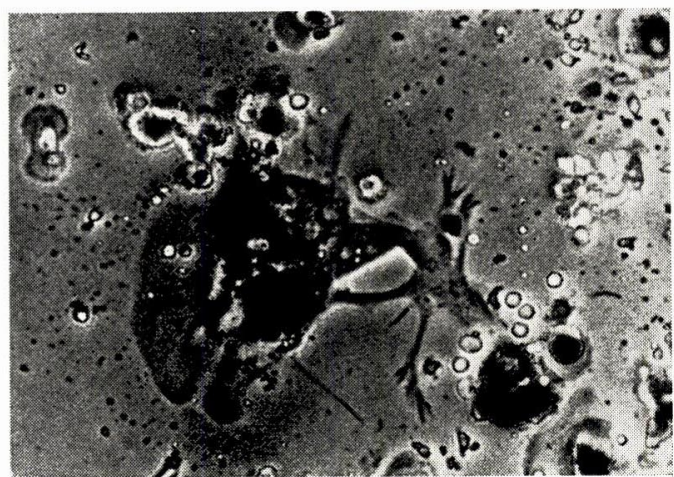

図 22 悪性黒色腫由来細胞。培養後10日目。多核 巨細胞。細手指様の細胞質突起がみられる。 16 ミリ映画フィルムより。(原倍率100倍)。

本腫瘍細胞はいずれも強い異型性を呈し, 図22 に示されるような多核巨細胞も存在し，その細胞 質突起は波動膜と移行するごとく観察された。核 の部分は白く透過性に見え，その形態は大型で異 型性を示し $1 \sim 2$ 個の核小体を有していた。細胞 分裂像は観察できなかった。

附随所見として認められた円形細胞は, 伸展さ れた腫瘍細胞の波動膜に附着したり，細胞質上を 活発に動きまわっていた。

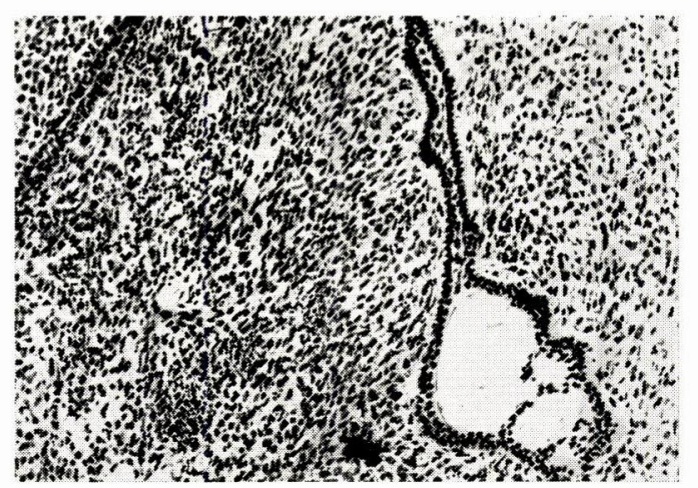

図 23 エナメル上皮肉腫組織切片標本。上皮細胞 が索状に配列している部分と, 異型性の強 以間葉性細胞より成る。H-E 染色。（原倍 率100倍)

v）エナメル上皮肉腫：培養後 $2 \sim 3$ 日目に母 組織のほぼ全周から 線維芽性細胞が遊出し, これ は原組織（図23）の線維芽性実質細胞と対応する ものと考えられた。細胞遊出は極めて緩慢であ り, 遊出初期には $5 \sim 10 \mu / \mathrm{hr}$ であった。細胞は細

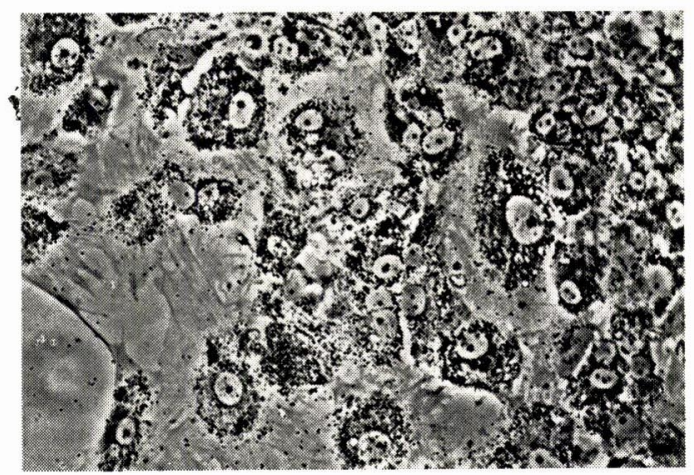

図 24 エナメル上皮肉腫由来細胞。培養後 6 日目。 異型性の強い線維芽性細胞集団。細胞質に は多くの顆粒がみられる。位相差像。（原 倍率100倍)。

長い多数の突起を伸ばしており，上皮細胞のよう な細胞配列を示すことはなかった（図24)。母組織 付近では細胞が密に配列し互いに重なり合い，細 胞境界は不明瞭であった。培養初期から細胞内に は多数の顆粒が存在し，その一部はガラス面に散 乱していた。

正常口腔組織由来の線維芽性細胞のような 細長 い細胞形態を示すことはなく, 円形に近いもので あった。細胞の動きは緩慢であった。核はその部 分のみ白くぬけて見え, 形は大型で円形〜棈円形 であり,核膜は不鮮明であった。多核細胞も多数認 められ，悪性細胞の特徴を有していた（図25）。核 小体は正円形を呈するのが特徵的であり, 数は 1 〜 3 個認めたが, 複数個存在する場合, そのらち 1

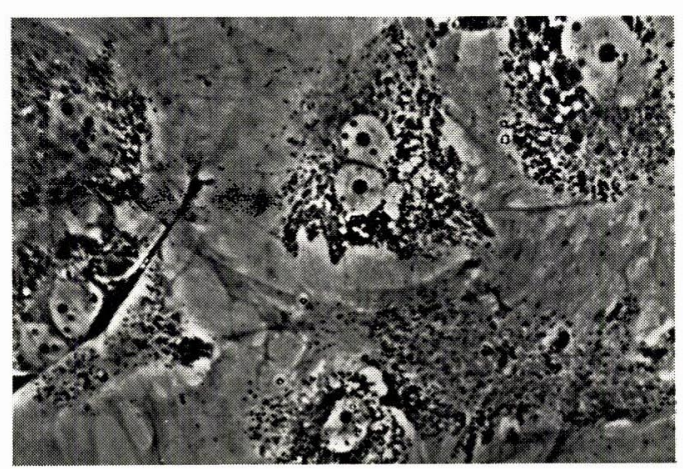

図 25 エナメル上皮肉腫由来細胞。図24の中等度 拡大。核は大型で，2核細胞も散見される。 核小体が明瞭な正円形を示すのが特徴的で ある。位相差像。(原倍率200倍)。 
個が大きく，他の核小体はかなり小型であった。

細胞分裂像は 培養初期にはみられなかったが, $4 \sim 5$ 日目になると散見されるようになり，分裂 期に変性するものも多かった。

培養初期に遊出した 細胞は線維芽性細胞のみで あったが，培養10日目頃に一部の組織片からは小 形の上皮性細胞がシートを形成し，線維芽性の肉 腫細胞を押しのけるようにして遊出してきた（図 26)。双方の細胞集団は独自の動きを示し, 決して 混ざり合うことはなかったが，上皮性細胞が活発 な増殖を示し，線維芽性細胞は変性していく傾向 がみられた。上皮性細胞は小型の 紡鍾形を呈して おり，エナメル上皮腫由来細胞と近似していた。

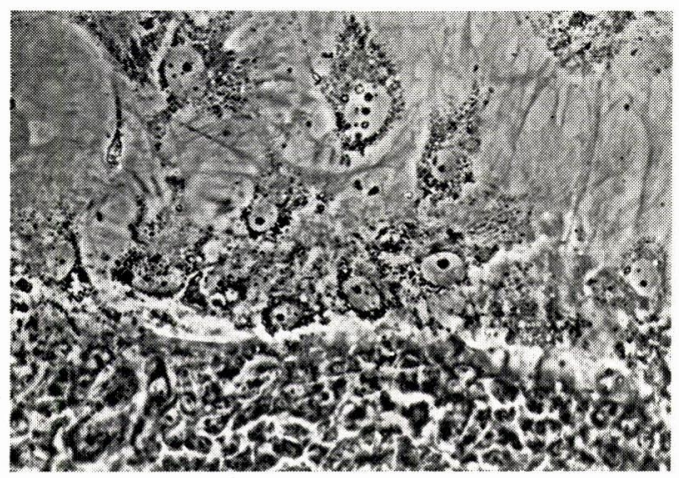

図 26 エナメル上皮肉腫由来細胞。培養後14日目。 上皮性細胞がシートを形成して遊出してい るのがみられる(下方)。線維芽性細胞は上 方に押し出されていった。位相差像。（原 倍率100倍)。

2. オートラジオグラフィーによる L.I. およ び M.I. の経日的維移の観察

${ }^{3} \mathrm{H}-\mathrm{TdR}$ 投与による 1 回標識法によって 測定さ れた L.I. および M.I. の計測值の 経日的推移の 様相はそれぞれ図27〜34に示す如くであった。

1）良性腫瘍由来細胞

本項目で観察されたのは多形性腺腫とエナメル 上皮腫のおのおの 2 例ずつ計 4 例であつた。標識 細胞および細胞分裂像は一般に少なく，かつ早期 に増殖能が減退する傾向にあった。

i) 多形性腺腫 : 本腫瘍では 2 例（症例 : B-1, B-2）について検索することができた（図27）。
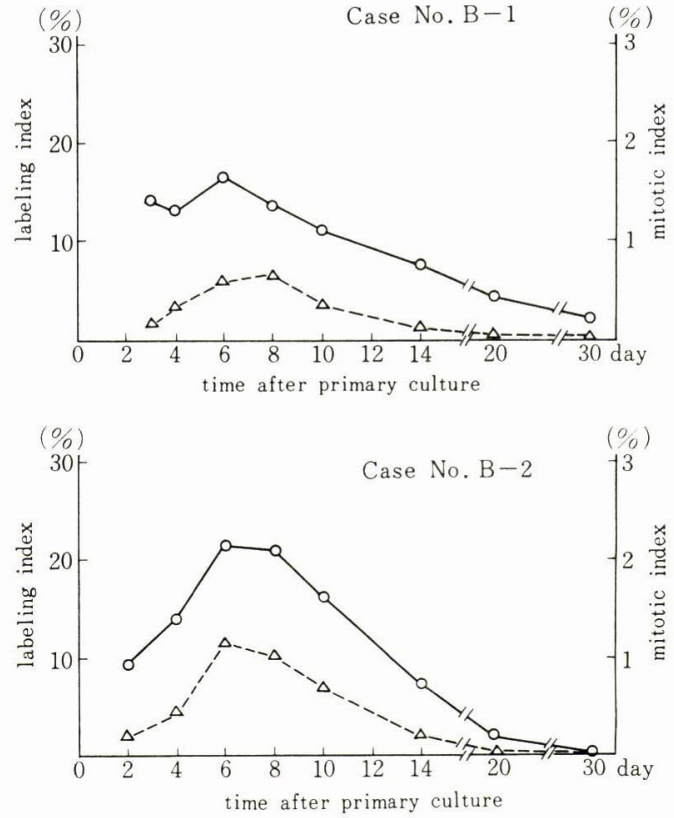

図 27 多形性腺腫由来細胞の L.I., M.I. の経 日的推移

$\mathrm{O}-\mathrm{O}$ : L.I., $\Delta \cdots \cdot \mathrm{A}$ : M.I.

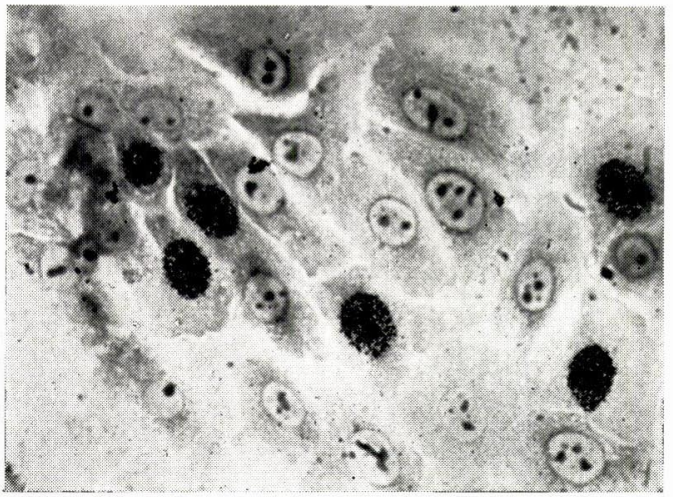

図 28 多形性腺腫由来細胞。培養後 8 日目。 ${ }^{3} \mathrm{H}$ TdR 1.5 時間投与後の標識細胞。ギムザ染 色。(原倍率300倍)

症例 B-1の L.I. は培養後 3 日ないし 10 日目 に10.9 16.3\%とほぼ安定した值を示したが（図 28)，その後徐々に低下していき，14日目にはや や低く7.1\%で，30日目には $2.1 \%$ あっあた。M.I. は 3 日ないし 10 日目では $0.2 \sim 0.8 \% ， 14$ 日目には $0.2 \% ， 30$ 日目には分裂像は見られなかった。 症例 B- 2 の L.I. は培養後 2 日目に $9.1 \%$ \% 
ったが，その後上昇を示して 4 日ないし 10 日目に は14.5 21.0\%の值をとった。しかし以後急速に 低下していき，14日目，7.5\%，30日目には標識細 胞は見られなかった。M.I. もほぼ同様の経過をた どり，2 日ないし 8 日目に0.2〜1.2\%，14日目に $0.2 \% ， 30$ 日目には分裂像は見られなかった。

ii）エナメル上皮腫 : 本腫瘍においても2 例 (症例：B-3, B-4) にっいて検索できた（図 29)。症例 B-3 については 培養後 2 日ないし20日 の期間では $9.0 \sim 17.3 \%$ と比較的安定したとりこ みがみられたが，M.I. は低く $0.1 〜 0.6 \%$ であ た。
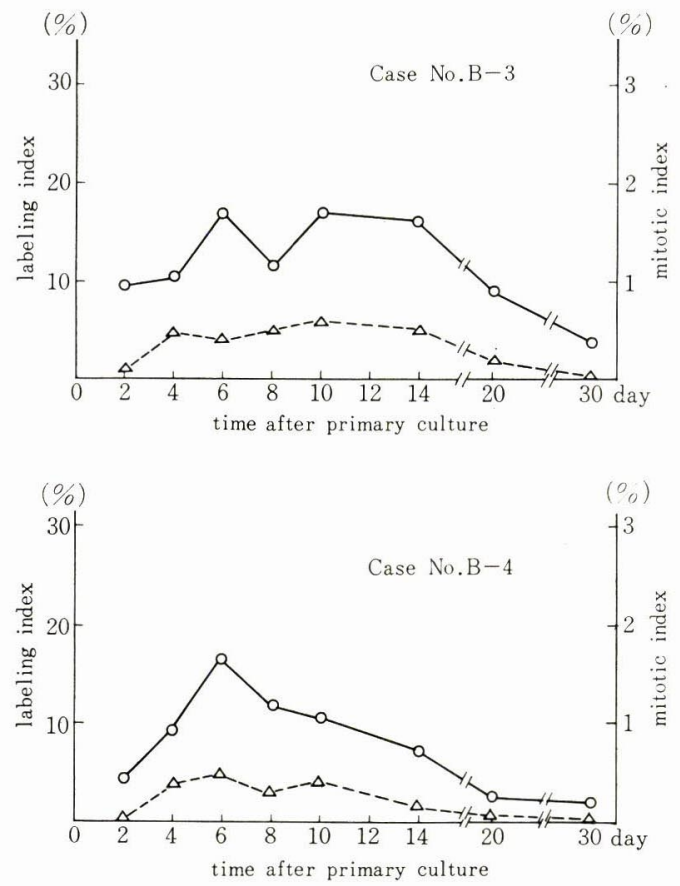

図 29 エナメル上皮腫由来細胞の L.I., M.I. の経日的推移

$\mathrm{O} \longrightarrow \mathrm{O}$ : L.I., $\Delta \cdots \Delta$ : M.I.

症例 B-4では 2 日ないし 6 日目にとりこみの上 昇が見られ（図30）４.4 16.5\%であったが以後 徐々に低下していき，14 日目，7.5\%，30日目， $2.1 \%$ でった。M.I. の值は低く，2 日ないし 6 日目に $0 \sim 0.5 \% ， 14$ 日目， $0.2 \% ， 30$ 日目には分 裂像は見られなかった。

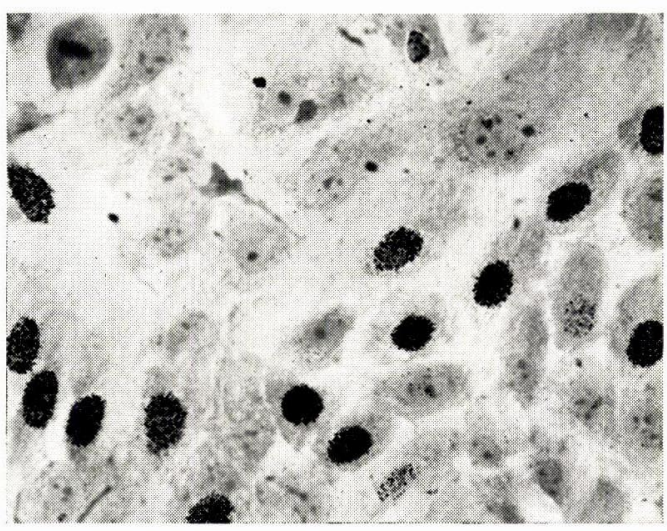

図 30 エナメル上皮腫由来細胞。培養後 6 日目。 ${ }^{3} \mathrm{H}-\mathrm{TdR} 1.5$ 時間投与後の標識細胞。ギム ザ染色。(原倍率300倍)。

2）覀性腫瘍由来細胞

本項目で検索できたのは扁平上皮癌，腺様囊胞
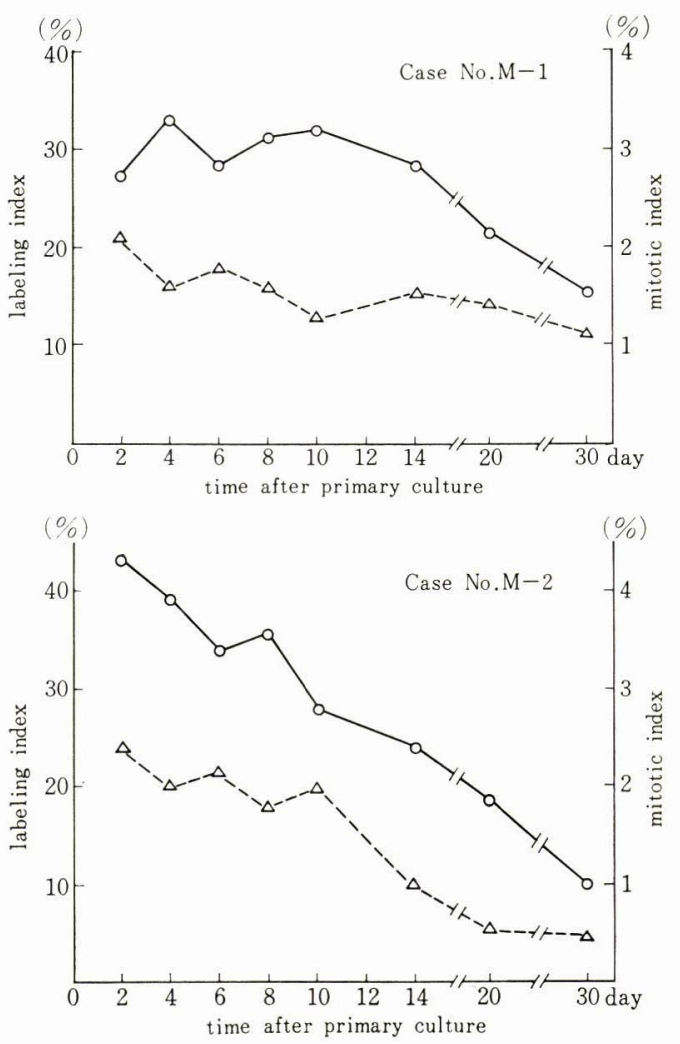

図 31 扁平上皮癌由来細胞の L.I., M.I. の経 日的推移

$\mathrm{O}-\mathrm{O}:$ L.I., $\Delta \cdots \Delta$ : M.I. 
癌, エナメル上皮肉腫の 3 腫瘍であった。これら のうち扁平上皮癌では特に高い L.I. を示したが, エナメル上皮肉腫では最も低值であった。

i) 扁平上皮癌 : 本腫瘍では 2 例（症例 : $\mathrm{M}_{-}-1$, M-2)について検索できた(図31)。M-1では培養 初期から高い值を示し (図32)， L.I.は 2 日ない し14日の期間に27.2 33.3\%であった。その後も それほど変動がなく高值を維持し，20日ないし30 日目には15.7〜21.8\%であった。

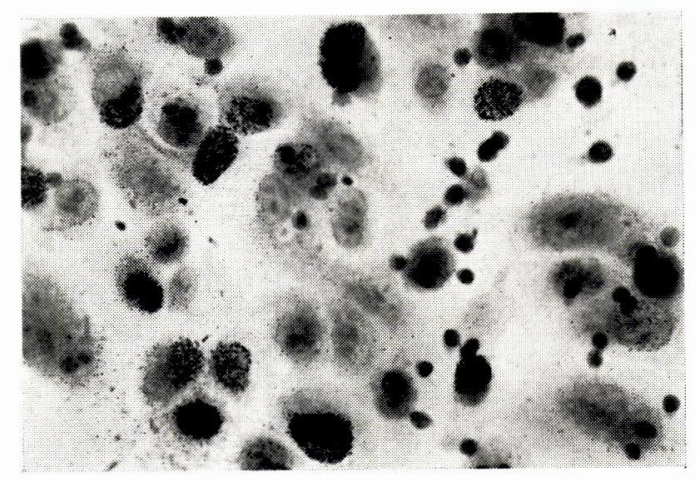

図 32 扁平上皮癌由来細胞。培養後 2 日目。 ${ }^{3} \mathrm{H}$ TdR 1.5 時間投与後の標識細胞。異型性を 示す核にとりこみがみられる。小型の細胞 はリンパ球で，とりこみはみられない。ギ ムザ染色。(原倍率300倍)。

M.I.は 2 日ないし30日目において, 2.1〜1.1\% の值であった。症例 $\mathrm{M}-2$ も同様に多数の標識細胞 がみられたが，培養経過とともに徐々に減少して いった。すなわち 2 日ないし10日目において 27.5 〜 43.9\%，14日ないし30日目に10.1〜23.5\%であ り，M.I. は2 日ないし10日の期間で，2.0〜2.4 \%，14日ないし 30 日目には0.3〜1.6\%であった。

ii) 腺様囊胞癌 : 本腫瘍では 1 例 (症例 : M-3) についてのみ検索できた (図33)。3 日ないし 8 日 目には12.2 16.8\%のやや高い值であったが，以 後低下していき，10日目，11.6\%，30日目，1.7 $\%$ の值を示した。M.I. は 3 日ないし10日目に0.5 〜 1.4\%と上昇したが， 14 日目， $0.6 \% ， 30$ 日目に は分裂像は見られなかった。

iii）エナメル上皮肉腫：本腫瘍は本来稀なも のであるが，たまたま 経験した 1 例（症例：M-

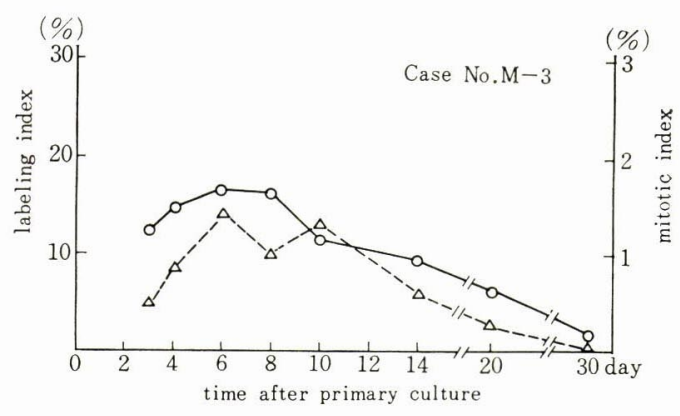

図 33 腺様囊胞癌由来細胞の L.I., M.I. の経 日的推移

O—O : L.I., $\Delta \cdots \Delta$ : M.I.

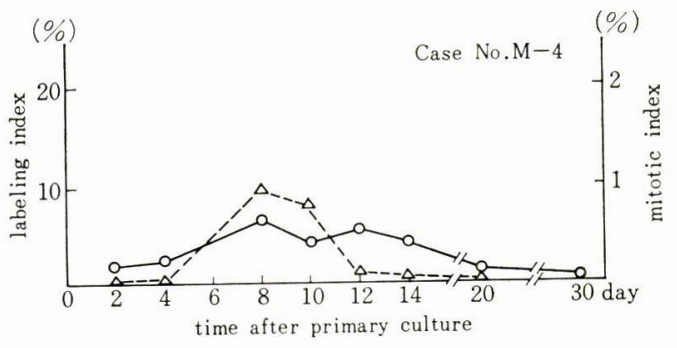

図 34 エナメル上皮肉腫由来細胞の L.I., M.I. の経日的推移

O-O : L.I., $\Delta \cdots \Delta$ : M.I.

4) について検索し得た（図34）。前述のごとくそ の 2 種の主要構成細胞中, 線維芽性細胞について のみ測定した。L.I.は 2 日ないし 14日目に 1.5 6.5\%，20日ないし30日目には0〜1.0\%であった。 分裂像も極めて少数しか 観察されず，8 日ないし 12日目に0.1〜1.0\%を示したのみであった。

\section{IV. 総括ならびに考按}

臨床材料より得られた腫瘍組織の初代培養細胞 は，その形態，増殖の様相が 各症例により異な り，安定した培養成績が得られないために系統的 研究は少ない ${ }^{1,4,5)}$ 。これら組織の初代培養細胞に 関する報告は主として染色標本あるいは位相差顕 微鏡による形態学的観察によるものであり, 増 殖能について検索している報告は極めて少な $\sim^{3,4)}$ 。

Walker $(1965)^{3)}$, 小浜 $(1967)^{4)}$, Flaxman $(1972)^{11)}$ らは ${ }^{3} \mathrm{H}-\mathrm{TdR}$ 投与オートラジオグラフィ 
一も併用し，DNA 標識細胞の 観察を行なってお り,とくに小浜 ${ }^{4)}$ は cumulative labeling 法を応用 して世代時間の測定を試み，各種腫瘍細胞につい て比較研究を行ない，それぞれの腫瘍ごとに増殖 の様相が特徵ある型を示すことを推定している。

一方, これら腫瘍の初代培養細胞の動態追究に 顕微鏡映画法を応用し，その形態，動きの特徵な どを系統的に検索した報告はわずかに Sherwin ら $(1968)^{6)}$ が行なっているのみであり, さらに オートラジオグラフィーによる細胞集団の増殖能 の所見とを比較検討している報告は見当らなかっ た。

前報9)において著者は，これらの方法を用いて ヒト口腔上皮細胞について動態観察を行なった結 果について総括し， 口腔腫瘍細胞の動態追究を行 なっていく上での基礎の確立を試み，一応の成果 を得た。今回はそれらをもととして，同様の方法 を応用して口腔領域腫瘍細胞について 検索した結 果を総括し，考按する。

\section{1. 培養法㧍よび培養液}

口腔腫瘍組織より得られた培養材料は種々なる 細胞集団から構成されており，それらから均一 な細胞集団を得ることは困難である ${ }^{4,8)}$ 。とくに口 腔内には無数の細菌が常在しており，それらと ともに変性壊死巣を形成している腫瘍組織も少 なくない4)。また in vitro に馿化し 難い初代培 養細胞の良好な培養成績を挙げるためには，もと の組織の細胞構成をできるだけ維持したまま培養 に移すのが好ましいものと考えられる。従ってト リプシン処理による単層静置培養によっては種々 な細胞集団より構成されている組織, 特に壊死層 を形成し易い腫瘍の場合には均一な増殖細胞集団 を得ることが容易ではなく，良好な培養成功率を あげることは困難と推定された。またトリプシン は上皮性細胞の増殖を抑制する傾向があるため, 線維芽性細胞の増殖を助長することも報告されて いる ${ }^{12,13)}$ 。これらの理由からトリプシン処理によ る単層静置培養は口腔腫瘍の場合には不適当と考 え, 本研究においては, 直接カバーグラス法 ${ }^{14)} に$ よる移植片培養を採用して, すべての培養を行
なった。本法による培養では, 上皮性細胞が良好に 増殖する例では線維芽性細胞が混在してきても, 培養後10日以降のことが多かった。また線維芽性 細胞が混在してきても, 当該カバーグラスを除去 するか ${ }^{8)}$, または線維芽性細胞集団のみを, police$\mathrm{man}^{13)}$ あるいは金属製針 ${ }^{15)}$ などを用いて除去する ことが可能とされている。著者は以上の方法によ る線維芽性細胞の除去法とともに，均一な腫瘍細 胞集団の見られた部分のみをカバーグラスを分割 して分離することも行なって所期の目的を果した が，簡便にして確実な良い方法であると考えてい る。また直接カバーグラス法によると映画撮影の 際，培養体の附着したカバーグラスを閉鎖気相の TD-15号ビンに静置することが容易で，かつ安定 した腫瘍細胞の培養所見を得ることができた。

培養液については前報9) の口腔上皮細胞におけ ると同様に Eagle MEM ニッサンのみを用い, 腫瘍細胞の 良好な培養成績を挙げることができ た。顕微鏡映画撮影法については前報で総括した 結果, 動態解析に十分役立てられることが判明し たため，本報においても同様に行ない良好な結果 を得ることができた。

2. 顕微鏡映画法による細胞動態について

1）良性腫瘍由来細胞

本研究におにて組織培養の対象とされた良性腫 瘍の研究報告としては, 多形性腺腫では Favata ${ }^{16)}$

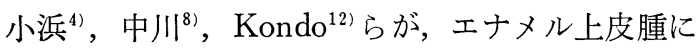

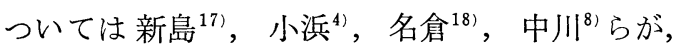
また神経鞘腫に関しては Schlumberger ${ }^{19)}$, Lane ら ${ }^{20)}$ の報告がみられているが，エナメル上皮線維 腫についての報告は見られなかった。

腫瘍細胞の遊出開始期は, 口腔上皮細胞 ${ }^{9)}$ に比 して遅く，2〜4 日後にみられたが，既報告の結 果をみても本報告同様良性腫瘍では比較的遅いよ うである ${ }^{3,8)}$ 。また細胞遊出速度も遅く, 個々の細 胞の波動膜運動は一般に不活発であった。

遊出細胞シートの外形について言及した 報告は 少なく ${ }^{21)}$ ，本研究ではその点を観察したところ， それぞれの腫瘍ごとに特徴的な形を示すことが明 らかになった。これは各腫瘍の細胞形態, 動き, 
細胞間結合様式などと密接な関係を有するものと 考えられた。

細胞間結合は良性腫瘍では一般によく保たれて いたが，1 数個の細胞がシートから離れて個々 に遊出する所見もわずかであったが観察された。 このことは口腔粘膜上皮細胞には見られなかった 点であり， 細胞間結合性がやや低下しているもの と推測された。

個々の細胞の形態につにては多形性腺腫, エナ メル上皮腫では，既に 2,3 報告されており ${ }^{4,8)}$, 本研究における如く顕微鏡映画法を採用した実験 結果においても，細胞異型性は軽度であり，ほぼ 均一な円形ないし 紡錘形細胞が主体を占めている 点は既報告とほぼ共通していた。一方エナメル上 皮線維腫の培養例で, 線維芽性細胞が主として遊 出し，極性を失なった細胞配列を示していたこと は, 本研究で初めて得られた特徵的所見であっ た。以上のような培養例に対し, 原腫瘍組織細胞 に相応し独得な 細胞形態を示す良性腫瘍として は，神経鞘腫を挙げることができる。本腫瘍の培 養体からは主として 2 種類の細胞, すなはち比較 的小さい microglia 由来と思われる細胞と, 長い 突起を有する細胞とが観察された，前者は一定の 極性を示すなど，その配列様式が特徴的であり， また後者は他組織由来線維芽性細胞に較べて 形態 的にかなり異なっている点が興味深かった。Lane $ら^{20)}$ は肺の同腫陽を培養し，その細胞形態の特徵 から診断を一層確かなものにすることができたと 述べ, 臨床診断の上に初代培養細胞所見が 有益で あることを示唆している。

これら良性腫瘍細胞は一般に培養日数が経過し ても著明な形態的変化を示すことが少なかつた点 は，前報9)の口腔上皮細胞あるいは本報告の悪性 腫瘍細胞とも異なる点である。

2）悪性腫瘍由来細胞

口腔領域においてみられる悪性腫瘍としては扁 平上皮癌, 腺癌, 肉腫などがあり, 最も頻度の高い

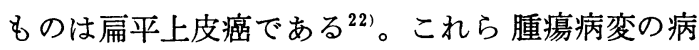
理組織学的 ${ }^{23)}$, あるいは臨床細胞学的検索 ${ }^{24,25,26)}$ からは著明な異型性を示す腫瘍細胞の 出現が既に
明らかにされている。一方これら 組織の初代培 養による所見 ${ }^{2,4,8)}$ をると, 悪性腫瘍細胞の特 徵が in vitroにおいても維持されており，とく に形態, 増殖能, 染色体構成において正常ある いは良性腫瘍細胞と較べ著しい变異を示してい る。

扁平上皮癌の培養報告は比較的多く, 口腔領域 由来細胞を用いたものは Silverman ${ }^{21}$, 小浜 ${ }^{4)}$ ，中 $川^{8)}$ ，Rangan ${ }^{27)}$ らのもが，また腺系悪性腫瘍に ついては小浜 ${ }^{4)}$, Southam ${ }^{28)}$, Sherwin $ら^{6)}$ の報告 が, 悪性黒色腫では $\mathrm{Cobb}^{29)}, \mathrm{Brown}^{30)}, \mathrm{Kahn}^{31)}$ らのものが，粘表皮癌では小浜 ${ }^{4)}$, 中川多らの報 告が見られているが，エナメル上皮肉腫の報告は 見出し得なかった。

細胞遊出の開始時期は腫瘍により，また同じ組 織型の腫瘍でも症例により異なっていて，恒常性 が見出されなかったことが本群における特徴的所 見であつた。良好な培養所見が得られた扁平上皮 癌の場合は比較的早期に 遊出が開始され, 培養後 1 日ないし 2 日目に見られた例が多かったが，他 の腫瘍では 2 日ないし 3 日後にみられ，良性腫瘍 例と類似した所見も多かった。既報告の悪性腫瘍 細胞の遊出開始期をみると，培養 $15 \sim 20$ 時間後と 早期のものから ${ }^{6)} ， 2$ 日ないし 4 日後とやや遅い ものなど ${ }^{3,4)}$, 報告者により，あるいは症例により かなりの幅のあることが明らかにされている。

シートを形成する場合，不規則な形を呈するこ とが多かったが，不完全，部分的にしかシートを 形成せず，細胞が個々ばらばらに遊走してくる例 もあった。また細胞の波動膜運動は一般に活発で あり，シートを形成していても個々の細胞ないし は細胞集団として容易に分離する傾向があった。 これらのことは悪性腫瘍の細胞間結合性の低 下 $^{6,32)}$ と密接な関連を有するものと思われた。さ らに本研究の良好な増殖を示した例では， $6 \sim 7$ カ月後になっても単一ないし数個の細胞集団とし て, もとのシートから分離し，遠く離れた別個の 場所で分裂増殖し 細胞集落を形成し多層状態 ${ }^{6,33)}$ で増殖することもあったが，このような所見は 主として扁平上皮癌で 観察された。Sherwin ${ }^{6)}$ 
は肺の腺癌由来細胞につにて映画で観察を行な い，細胞間結合性の低下，および細胞の多層化を 認めており，これらのことは癌細胞の contact inhibition $^{34)}$ の低下と関連していると述べている。 また井坂 ${ }^{351}$ は実験動物腫瘍の知見から, 癌細胞の 最も特徴的な動態は個々の細胞の独立性にあり, 転移性増殖にその最も明瞭な姿が求められると述 べている。このような癌細胞の性質は臨床におい て原発巣の組織から分離し易いことと共通してい るものと思われ，癌の転移性増殖の第一条件を満 たしている点で興味深かった。

遊出した培養細胞の形態をみると，本研究では 上皮性細胞がその大部分を占めていたが，このこ とは原腫瘍に上皮性悪性腫瘍の多かったことと相 俟ち，その腫瘍実質細胞が遊出してきたものと考 える。しかし悪性黒色腫由来細胞では強い異型を 示寸線維芽性細胞や紡鍾形を呈する上皮性細胞も 数出く出現した。本腫瘍についての既報告をみて も Brown ら ${ }^{30)}$ ，Kahn ら ${ }^{311}$ は主として紡鍾形細 胞を, Cobb ら ${ }^{29)}$ は主として線維芽性細胞を観察 しており，報告者により相違がみられているが， 本研究では両者ともに観察追究することがとがで きた。また少数例において培養初期から多核巨細 胞も観察されたが，培養による報告はない。しか し本腫瘍の病理組織所見では石川 ${ }^{36)}$ が多核巨細胞 の出現を報告している。

一方これまで培養報告のみられなかったエナメ ル上皮肉腫と良性腫瘍の項で既述したエナメル上 皮線維腫では共通して, ほとんどの組織片から線 維芽性細胞が遊出し，6〜10日後になって一部の組 織片からはエナメル上皮腫由来細胞に類似した上 皮性細胞の遊出を見たが，これは原組織像（図 9, 23) から類推すると, 非上皮性細胞組織成分が腫瘍 組織の主体を占め, 上皮性細胞組織成分が相対的 に少なかったために, 線維芽性細胞の遊出が培養 初期から容易に行なわれたものと考えられる。 また遊出した双方の細胞集団は相互に波動膜によ り明瞭に境され，細胞結合を行なうことなく，ま た相互に混ざり合うこともなかった。既報告 ${ }^{37)} の$ 上皮性細胞と線維芽性細胞の混合培養下でも，両
者は別個の細胞集団を形成することが述べられて いるが，本研究結果と合わせてこれらの所見は培 養細胞の形態学的な同定法の一つとして有用なも のと考える。

腺様囊胞癌, 悪性黒色腫, 粘表皮癌において は，なお培養例数は少ないが，これらの間の共通 した所見として，細胞結合のほとんど見られない 細胞群に細長い形態を示す細胞質突起が見られ， これは扁平上皮癌を除く癌細胞に共通した特徵と して興味深かった。勝田 (1968) ら ${ }^{38)}$ はラッテ腹 水肝癌を用いた顕微鏡映画法による研究で，癌細 胞が細胞質突起を伸展して 正常細胞に附着し，そ こから養分を吸収して正常細胞を 死滅させていく ことを報告しているが，著者が観察した初代培養 細胞の細胞質突起の機能 等についてはなお明らか にすることができなかった。

悪性腫瘍組織から 遊出した細胞の大きさは一般 に培養初期から大型のことが多かった。この場 合，培養経過とともにさらに大型化し，細胞内顆 粒の一層の増加をきたしたり，多核巨細胞を形成 して増殖することなく変性に陥いっていく培養例 と, 分裂増殖を持続し, 培養日数の経過とともに 細胞が小型化し，ほぼ均一な形態を示す培養例と が経験された。このことは癌組織移殖片の種類, 性質, 増殖細胞集団の多寡, あるいは培養細胞の in vitro における適応力などに差異があるためと 考えられた。すなわち本研究で $6 \sim 7$ カ月以上に わたつて分裂増殖を行なった培養例は 母組織内に 比較的均一な細胞集団を有し，かつそれらが in vitro でも分裂増殖をくりかえしつつ厳しい培養 条件に対して適応 (adaptation) した結果，生き残 ったものと考えられた。このように長期間良好な 増殖を示した培養例は，頸部リンパ節より得られ た扁平上皮癌に比較的多く経験された。本組織か らの培養材料は無菌的に採取され易いこと，かつ 比較的均一な細胞集団が得られ易かったことが, その主要な原因と考えられた。しかしながら臨 床的にみて速やかな増殖や，転移形成を示したと しても初代培養所見が必ずしもそれに相応する ものではなく，得られた培養材料の良否，あるい 
は規定された培養条件に対する 各種組織由来培養 細胞の適応性などに差があると考えられるため, 培養成績もそれらに左右される面が出てくると思 われた。たとえば，悪性黒色腫は臨床的には悪性 度の高い腫瘍とされているが39)，本研究で経験さ れた 3 例では，遊出細胞は少なく，増殖もほとん どみられなかった。また本腫瘍の既報告の所見を みても，良好な培養成績を挙げることが 困難であ ると述べているものがいくつかみられた ${ }^{40-42)} 。 し$ かしその原因については，本研究では培養例が少 なく，明らかにし難いため，今後さらに検討が必 要とされよう。

円形細胞の動きをみると， 癌細胞のシートの中 では速やかな移動を行なうことは少なく，活発な 波動膜運動を行なう癌細胞に附着したり, 細胞質 の上を不規則に動きまわることが多かった。著者 は前報9)で細胞間結合が強く保たれている口腔上 皮シートの中では， 円形細胞が細胞間隙をぬって 速やかな運動を行なうが，ガラス面では位置移動 をほとんど行なわないことを明らかにした。また 本報の良性腫瘍細胞のシートの中でも前報におけ ると同様な所見が少数例に見られたが，これらの 点から考えると, 本研究の癌細胞のシートの中で は円形細胞の速やかな運動が 見られなかったこと は，癌細胞が細胞間隙を伴なった 規則的な細胞間 結合を有しないことに原因の一つがあると考えら れた。一方 Richters $ら^{43)}$, Sherwin $ら^{6)}$ も顕微鏡
映画による所見からリンパ球が広汎な 領域を運動 することなく，癌細胞に附着したり，癌細胞の周 囲を回転していたことを報告したが，本研究結果 と対応する所見を記載したものと考える。

顕微鏡映画法により特徽的に観察された核の回 転所見については，細胞分裂の前に見られたもの が多かったほかに，細胞質顆粒の活発な運動に伴 って起こるもの， あるいは活発な波動膜運動に伴 って起こる場合も見られ，Rose $(1965)^{44)}$ が記載し た所見と多くの点で一致していた。

3. 細胞分裂像について

細胞分裂の様相について要約すると 表 5 のごと くであった。良性腫瘍で細胞分裂像が観察された のは多形性腺腫とエナメル上皮腫であったが，そ の頻度は口腔上皮細胞に比して少なかった。また 神経鞘腫，エナメル上皮線維腫ではほとんど観察 できなかったが，これら所見からみると良性腫瘍 では細胞分裂像は一般に少なく，中川委が染色体 標本作製の際に分裂細胞を十分に 集めることがで きなかったと述べていることとも相応した 所見で あると思われる。また本研究では培養後 2 週間目 頃には増殖が衰え，細胞運動は緩慢になる傾向に あったが，小浜によると多形性腺腫由来細胞は長 期間培養可能例の多いことと共に，培養経過に従 い約 5 カ月目頃までは核異型性の増大ならびにい わゆる悪性細胞様の特徽的所見を示す培養例もみ られることが報告されている。

表 5 口腔各組織別細胞分裂の様相

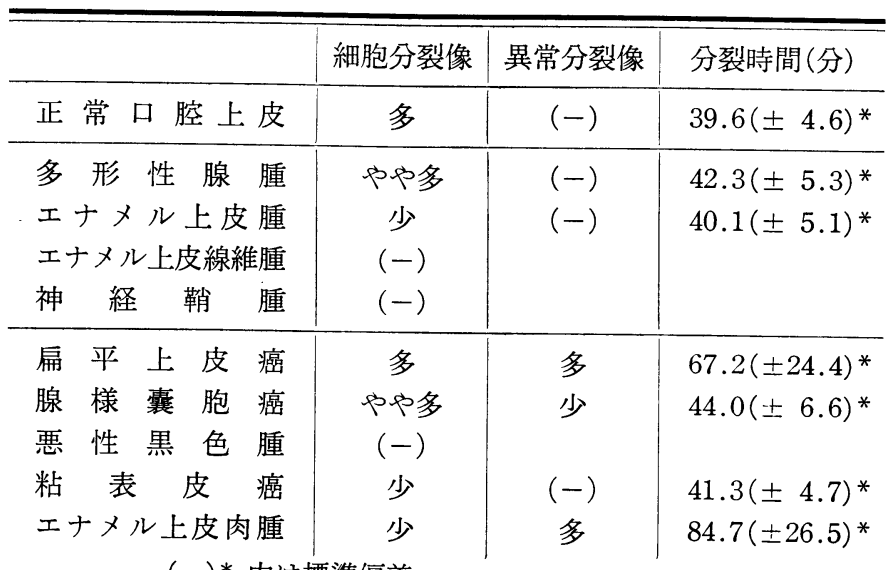


細胞分裂の際に多極分裂などの 異常像は見られ ず，分裂に要する時間も正常細胞のそれとほぼ同 様であった。

一方悪性腫瘍細胞では, 細胞分裂像が悪性黒色 腫に見られなかったほかはすべてに観察された が，分裂像には多数の異常が認められ，その主な ものは多極分裂，不等分裂などであった。顕微鏡 映画法を応用し初代培養細胞に㧍いて多極分裂が 観察できたことは本研究における新たなる知見と 考えられる。清水 ${ }^{24)}$ は位相差顕微鏡法による新鮮 細胞所見にて分裂異常像を報告するとともに，癌 細胞では球形化して過剩位相差量を示し八ローを 伴った白色光輝像を呈する 細胞が多数認められた のが特徵的であったと述べ，それらが細胞変性の 結果であろうと推定したが，本研究の映画法によ ると必ずしも変性細胞ではなく，むしろ活発なる 生活活動像としての細胞分裂像, あるいは分裂停 止像なども多数含まれているものと考えられた。 このことはまた臨床における位相差顕微鏡法によ る細胞学的検索に当って, 特徵的所見を新たに加 える一根拠をなすものとしての 意義を示すもので ある。一方山田 ${ }^{45)}$ ，大田 ${ }^{46)}$ らは固定染色法による 細胞診所見から癌細胞の 異常分裂像を報告してお り, 山田 ${ }^{45)}$ は多極分裂像も観察し, さらに分裂異 常像が細胞診で検出された場合には悪性腫瘍の疑 いが極めて濃厚であると述べている。

培養細胞における多極分裂像については，中 $川^{8)}$ が扁平上皮癌の 初代培養細胞の固定染色標本

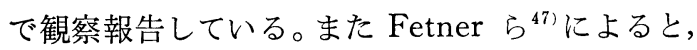
$\mathrm{KB}$ 細胞 ${ }^{48)}$ にはしばしば多極分裂像が観察され, X線照射を行なうとそれが増加することが明らか にされている。これら 異常分裂が出現する原因 としては諸説あるが ${ }^{47,49,50)}, \mathrm{Puck}^{499}$ は培養細胞が in vitro の劣悪な環境の中で示す動態の一つであ るとし，また Wakonig ${ }^{50)}$ は無秩序に増殖する細 胞集団が示す現象の一つであると述べている。本 研究では悪性腫瘍細胞にのみ観察し得たが, 既報 告の細胞診所見 ${ }^{24,45,46)}$ や初代培養所見 ${ }^{8)}$ でも悪性 腫瘍細胞についてのみ報告されており，異常分裂 像は悪性腫瘍細胞の性状と関係が深いものと推定
された。一方多極分裂を行なう細胞は同一の 細胞 集団に多発する傾向もみられたが，これは中川 が悪性腫瘍の染色体数分布において $3 \sim 4$ 倍性な ぞ高倍性細胞を報告している点を考え合わせても 興味ある所見であり，今後これらの関連を検索し ていく必要があろう。また分裂をその中期で停止 (mitotic arrest) する細胞あるいは分裂の途中で 死滅していく細胞も多く, 悪性腫瘍細胞が比較的 容易に細胞死を起こすことが推測された。

細胞分裂に要する時間は口蓋粘膜上皮細胞，良 性腫瘍細胞が約 $40 \sim 42$ 分で比較的一定した 分裂時 閒であったのに較べて，悪性腫瘍細胞においては 一般に延長しており，形態的に異常分裂を示す場 合には著明な延長がみられた。その際これらの細 胞が分裂中期に長く停滞していることが見出され たが，これもまた特徵的所見であった。培養細胞 の分裂時間についての報告はいくつか見られてお $り^{51,52,53)}$ 報告者により差異があるが，Hela 細胞

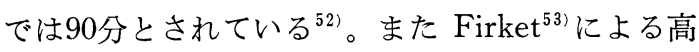
等脊椎動物では $37 \sim 38^{\circ} \mathrm{C}$ で $40 \sim 90$ 分の範囲の長 さであったとしている。これら報告を総合すると， 分裂時間は細胞の種類, 培養条件, 測定方法の違 いなどにより異なってくることが推定される。本 研究では前述したような同一条件下で培養を行な い，正常上皮および良性腫瘍などの良性細胞では 約40〜42 分とほぼ一定していたが，墨性腫瘍細胞 では一般に延長し44〜85 分にわたっており，かつ 同一症例でも細胞間に著明な 差異ばらつきがみら れ，これは悪性細胞の特徵的所見であった。

4. L.I. と M.I. の経日的推移と世代時間につ いて

オートラジオグラフィーを用いて 各種腫瘍組織 の in vitro の増殖能を推定しようとする試みは Oehlert $(1963)^{54)}$ ほか数多くみられている ${ }^{55-57)}$ 。 口腔腫瘍組織に関して, 関山 $(1965)^{55)}$ は in vitro の短期培養について, また山城 ${ }^{57)}$ は器官培養を応 用した実験から各腫瘍ごとに特徴ある 標識細胞所 見を報告している。しかしヒト腫瘍初代培養細胞 を用いて DNA 合成状態を検索した報告は少な $く$, Walker $^{3)}$, 小浜 ${ }^{4)}$, Flaxman ${ }^{11)}$ らのものを見 
るにすぎない。また経日的推移の観察による報告 は見当らず，著者はこの点も含め検索を行なった。

${ }^{3} \mathrm{H}-\mathrm{TdR}$ の投与量および投与時間については前 報9）と同様 $0.5 \mu \mathrm{Ci} / \mathrm{ml}$ の溶液 $1 \mathrm{cc}$ を 1.5 時間投与.

して行ない，観察し易い細胞のとりこみ像を得る ことができた。シートの中の DNA 標識細胞およ び細胞分裂像の分布状態をみると，培養初期から シート全体にほぼ均等に分布していた。この点に ついては小浜 ${ }^{4)}$ も同様のことを報告しており， 口 腔上皮細胞の場合と 異なる所見であった。従って L.I. および M.I. の計測にあたってはシート全域 の細胞を対象として行なった。腫瘍細胞の L.I. 值は報告者により異なるが4,54)，これは臨床材料 の場合，個体差や得られた培養材料の生物学的観 点よりみた良否，培養方法の相違などが結果を大 きく左右する可能性があるので，本研究では同一 条件下で実験し, 各腫瘍細胞について経日的推移 の様相を比較検討した。

本研究と同様の組織および培養法を用いた実験 報告としては小浜" によるものがみられている。 それによると培養後15日ないし20日目に 1 回標識 法により得られた標本から計測した L.I. の值は, 良性腫瘍の多形性腺腫では 8 15\%のものが多く, 扁平上皮癌では 30 40\%のものが多かったとさ れている。一方関山吕, 山城 ${ }^{57)} ら$ の行なった in vitro の腫瘍組織の標識指数の 所見からは 扁平上 皮癌由来組織が高值を示すが，良性腫瘍では一般 に低值であることが明らかにされている。しかし これらは培養下における経日的推移についての詳 細な検索を行なっていない。本実験では腫瘍細胞 の L.I. は扁平上皮癌が特に高く, エナメル上皮肉 腫が最も低かった。これら L.I. を経日的推移より みると，良性腫瘍では培養初期にやや低く，4 日 ないし10日頃にほぼ安定していたが，良好な增殖 のみられた扁平上皮癌においては培養初期の 2 日 目から高い值を示し，長期間持続する傾向があっ た。癌細胞の L.I. が培養初期から高值であったこ とは，良性細胞に較べて大きな相違点であった。 このことは後述するように扁平上皮癌と正常口腔 上皮の世代時間があまり変わらないにもかかわら
ず，DNA 合成時間が扁平上皮癌の方が相対的に 長いことや，培養初期に同調的増殖を行なってい ることもその原因と考えられる。しかし詳細な検 討は今後の研究に待つべきであろう。

L.I. 值については, 顕微鏡映画法による所見を 考慮すると，癌細胞では分裂時間の延長なども，そ の数值に影響を及ぼしていることが推測される。

また比較的安定した L.I. および M.I. を示し, かつ両者の推移曲線がほぼ相似の関係にあつた培 養後約 4 日ないし10日の期間では増殖過程にある 細胞が安定した增殖を示しているものと考えられ る。著者 ${ }^{9)}$ は正常口蓋粘膜上皮の 初代培養細胞の ほとんど全細胞が DNA 合成を行なう初期増殖期 には cell cycle の解析が可能であることを示した が，本実験の腫瘍細胞においてもその時期に全細 胞が cell cycle に関与し, 対数的増殖をしている ものと仮定すると次の 関係式が成立する。すなわ ち, 普通平衡状態にある細胞集団では世代時間 $t_{G}$, 分裂時間 $T_{\mathrm{m}}$ および分裂指数 M.I. の間には次式 によって与えられる様な関係がある。

$$
\mathrm{t}_{\mathrm{G}}=\frac{\mathrm{T}_{\mathrm{m}}}{\text { M.I. }}
$$

しかしながらここで仮定したような対数増殖を示 す細胞集団では, 式 (1) で与えられる関係に或る. 修飾を必要とし，その世代時間を $\mathrm{T}_{\mathrm{G}}$ とすると, 平衡状態の細胞集団の世代時間 $t_{G}$ との間には

$$
T_{G}=t_{G} \times \log _{e} 2 \ldots \cdots \cdots \cdots(2)
$$

なる関倸が成立する ${ }^{58)}$ 。

一方 DNA 合成期の長さを $T_{s} と し ， D N A$ 標 識指数を L.I. とすれば世代時間 $T_{G}$ との間の関 係は

$$
\mathrm{T}_{\mathrm{S}}=\mathrm{T}_{\mathrm{G}} \times \text { L.I. } \cdots \cdots \cdots \cdots(3)
$$

によって与えられるから, 式 (1)，(2) および(3) によって

$$
\mathrm{T}_{\mathrm{s}}=\frac{\mathrm{T}_{\mathrm{m}}}{\text { M.I. }} \times \text { L.I. } \times \log _{\mathrm{e}} 2 \ldots \ldots \ldots
$$

が得られる。式 (4) の $T_{m}$, M.I. および L.I. の それぞれに実験によって得られた值を代入して計 算された各腫瘍細胞にっいての世代時間 $T_{G}$, DNA 合成時間 $T s$ を表 6 に示す。 
表 6 口腔各組織別世代時間各期の長さ

\begin{tabular}{l|c|c|c|c}
\hline \hline & labeling index* & mitotic index* & DNA合成時間 & 世代時間 \\
\hline 正常口腔上皮 & $18.5( \pm 4.0)$ & $1.0( \pm 0.1)$ & $12.1^{\text {時間 }}$ & $66.2^{\text {時間 }}$ \\
多 形 性 腺 腫 & $18.3( \pm 3.5)$ & $0.8( \pm 0.4)$ & 11.2 & 61.0 \\
エナメル上皮腫 & $11.7( \pm 3.5)$ & $0.4( \pm 0.1)$ & 13.5 & 115.7 \\
\hline 扁 平 上 皮 癌 & $31.8( \pm 2.8)$ & $1.7( \pm 0.1)$ & 14.5 & 45.6 \\
腺 様 霅 胞 癌 & $14.9( \pm 2.3)$ & $1.1( \pm 0.3)$ & 6.9 & 46.6 \\
エナメル上皮肉腫 & $6.6( \pm 2.2)$ & $0.7( \pm 0.3)$ & 9.2 & 139.8
\end{tabular}

* 培養後 $6 \sim 8$ 日の平均值, ( ) 内は標準偏差

DNA 合成時間 $\left(T_{\mathrm{s}}\right)$ は扁平上皮癌が14.5時間で 最も長く, 腺様囊胞癌が 6.9 時間で最も短かった が，本実験の培養細胞ではこのように腫瘍ごとに その值に差がみられた。 Moorhead (1963) ら59 によると増殖が安定している株細胞などでは， S 期は細胞の種類や世代時間の長さに関係なくほぼ 一定し， 7 ～時間であったと 報告しているが， 本実験で用いたような臨床材料より得られた 腫瘍 の初代培養細胞では，その細胞間に DNA 量など に多様な変異があることも考えられ， $\mathrm{S}$ 期の長さ にもその影響が現われるものと推定された。この ことは中川 ${ }^{8\rangle}$ が報告した本領域腫瘍の染色体分析 結果に扔いて，その形，数に変異が著しいことに も相応しているものと考えられる。

世代時間はエナメル上皮肉腫が最も長く 139.8 時間, 次いでエナメル上皮腫の 115.7 時間, 多形 性腺腫の 61.0 時間の順であった。扁平上皮癌, 腺 様囊胞癌はやや短かく, それぞれ45.6時間, 46.6 時間であった。これらの值は小浜 ${ }^{13)}$ が口腔腫瘍初 代培養細胞に cumulative labeling 法を応用して 測定した世代時間の 50〜108 時間よりもやや短か い值であった。

McDonald (1962) ${ }^{60)}$ Monesi (1962) ${ }^{60)}$ らによる と，培養細胞の世代時間は 累代とともにある限度 まで漸次短縮することが明らかにされており，と りわけ樹立株細胞の報告を見ると一般に短か い62)。これは累代培養細胞の方が細胞間の個体差 が少なくなるため，より安定した正確な值を示す ものとも考えられる。一方著者ら ${ }^{63)}$ が行なった正 常口腔線維芽性細胞では約30時間と, 口腔上皮あ
るいは腫瘍細胞に較べて短かった。このように初 代培養細胞では由来組織により世代時間に種々の 差異が認められたが，個体差のある各腫瘍の同一 条件下での值の単純な比較に当っては注意を要す る。

以上述べたよらに，顕微鏡映画法とオートラジ オグラフィーを併用することにより， 口腔腫瘍初 代培養細胞の動態解明の上にいくつかの 利点を有 することが判明したが，今後これらの動態を一層 明確にし，臨床において多様性を示す悪性腫瘍の 診断，治療法の選択，さらにはそれらの本態解明 のために役立てられるものと考えている。

\section{V. 結 論}

1. 直接カバーグラス法により得られた口腔腫 瘍組織の初代培養細胞の動態について，16ミリ微 速度顕微鏡映画法と ${ }^{3} \mathrm{H}-\mathrm{TdR}$ 投与 オートラジオ グラフィーとを併用して検索を行ない，各種腫瘍 由来細胞の特徵を把握することができた。

2. 良性腫瘍由来上皮性細胞は一般にシートを 形成して遊出し，細胞間結合を保った比較的均一 な細胞集団より成っていた。また細胞の動き，増 殖は緩慢な例が多かったが，シートの形，細胞形 態などは各腫瘍，培養例によって特徽的所見を認 めた。

3. 悪性腫瘍由来細胞は, 明瞭なシートを形成 することが少なく，細胞間結合も弱く，細胞異型 性が著明であり, 細胞の動き, 増殖は活発な例が 多かった。

4. 悪性腫瘍由来細胞 では, $6 \sim 7$ 箇月以上に 
わたって活発な分裂増殖を行なう培養例もあり， これらの例は次第に比較的小型の均一な 細胞集団 を形成していく傾向にあり，細胞が重層化してい く所見もみられた。

5. 悪性腫瘍由来細胞には，多極分裂などの異 常分裂を行なうものが観察され，分裂の途中で変 性壊死に楩いる場合も多く，分裂に要する時間は 著明に延長し，44 85分にわたっていた。

6. 円形細胞は，活発な分裂增殖下にある 覀性 腫瘍細胞でその細胞間結合が弱く，かつ不規則な シートでは，その運動速度が遅かった。

7. ${ }^{3} \mathrm{H}-\mathrm{TdR}$ 投与オートラジオグラフィーの所 見によると，腫崵細胞では DNA 標識細胞および 細胞分裂像がシート全体にほぼ均等に分布してお り，かつ培養初期から高い L.I., M.I. を示すこと が多く，とりわけ扁平上皮癌では長期間高い值を 示していた。

8. L.I. と M.I. の経日的推移の曲線はほぼ相 似の関係が認められ，本実験における腫瘍細胞に おいても DNA 合成を行なった細胞のほとんど が分裂を行なっていくものと考えられた。また L.I., M.I. 抢よび分裂時間の計測值から DNA 合成時間，世代時間を求めたところ，前者では 6.9〜14.5時間，後者では45.6〜139.8時間であり， 各種腫瘍間に差が認められた。

9. 顕微鏡映画法とオートラジオグラフィーと を併用し，両者の利点を生かすことにより培養細 胞の動態に関して, 一層正確な知見が得られた。

\section{謝 辞}

稿を終わるに当り, 終始, 御懇篤な御指導と御教示を 賜わった当教室主任上野正教授ならびに御教示と御校閲 を賜わった本学歯学部口腔病理学教室石川梧朗教授, 同 歯科放射線学教室中村正教授汇梁甚の感謝を捧げます。 また終始御指導を賜わった当教室清水正嗣助教授，小浜 源郁講師に事心より感謝を捧げるとともに，オートラジ オグラフの解析法について御教示を頂いた本学歯学部㐘 科放射線学教室佐々木武仁助教授, また種々御助力, 御 鞭撻下さった当教室道健一講師，中川茂美博士，埼玉医 科大学山城正宏助教授，ならびに当教室員各位に哚甚の 謝意を表します。
本論文の要旨は $1972($ 昭 47$)$ 年 4 月 8 日第 26 回日本口腔 科学会総会において発表した。

な抢本研究は，1971(昭46)年度文部省癌特別研究費に よる「口腔悪性ならびに前癌性病変の 組織培養法による 診断と治療法選択阔する研究」の一環として行なわれ たことを付記する。

\section{文献}

1) Paul, J.: Cancer cells in vitro: A review, Cancer Res., $22:$ 431, 1962.

2) Silverman, S. Jr.: Tissue culture studies of human oral carcinoma, I. proliferative capacities of nonmalignant and malignant oral explants, J. Dent. Res., 42: 1439, 1963.

3) Walker, D. G., Lyons, M. M. : Observations on primary short-term cultures of human tumors, Europ. J. Cancer, $1: 265,1965$.

4）小浜源郁：ヒト口腔領域の各種非腫瘍ならびに 腫瘍組織の組織培養学的研究——形態学的特徴 ならびに増殖能について一，口病誌，34:393， 1967.

5) Jones, G. W.: Primary and metastatic epithelial tumors of the human kidney and bladder in tissue culture, Cancer, $20: 1893$, 1967.

6) Sherwin, R. P., Richters, V. and Richters, A.: The documentation and behavior of human lung cancer in short term tissue culture, Tokyo, 1968, University of Tokyo Press, p. 3.

7) Israeli, E., Bartilai, D.: Some characteristics of human cancer tissues in vitro, Cancer, $25: 824,1970$.

8）中川茂美：ヒト口腔領域の非腫瘍ならびに腫瘍 初代培養細胞の形態学的特徴ならびに染色体に 関する研究, 口病誌, $38: 73,1971$.

9）曰田篤伸：ヒト口腔各種組織初代培養細胞の動 態に関する顕微鏡映画法ならびにオートラジオ グラフィーによる研究, 第 1 報. 口腔粘膜上皮 細胞について，口病誌，39:196，1972.

10）小川和朗 : 細胞の機能，新細胞学，東京， 1965 年, 朝倉書店, 243 頁.

11) Flaxman, B. A. : Growth in vitro and induction of differentiation in cells of basal cell cancer, Cancer Res., 32 : 462, 1972.

12) Jensen, F. C., Gwatkin, R.B.L. and Biggers, J. D. : A simple organ culture method which allows simultaneous isolation of specific types of cells, Exp. Cell Res., 34 : 440, 1964.

13) Kondo, T., Muragishi, H. : A cell line from a human salivary gland mixed tumor, Cancer, $27: 403,1971$. 
14）小浜源郁：ヒト口腔組織の培養法の一考案につ いて, 口病誌, $36: 206,1969$.

15) Williams, G. M., Weisburger, E. K. : Isolation and long-term cell culture of epitheliallike cells from rat liver, Exptl. Cell Res., $69: 106,1971$.

16) Favata, B. V.: Characteristics of mixed tumors on the parotid gland glowing in vitro, Surg. Gynec. \& Obst., 86 : 659, 1948.

17) Niijima, M.: Tissue culture of an ameloblastoma, Zschr. F. Zellfosch., 46 : 127, 1957.

18）名倉秀明：エナメル上皮腫の培養(会), 第 9 回 口腔組織培養研究会記事, 1971, 17頁.

19) Schlumberger, H. G.: Nerve sheath tumors in an isolated goldfish population, Cancer Res., 12 : 890, 1952.

20) Lane, N., Murray, M. R. and Fraser, G. : Neurilemoma of the lung confirmed by tissue culture, Cancer, $6: 780,1953$.

21）新島迪夫：上皮組織の培養, 組織培養一基礎 と応用一，東京，1964，朝倉書店，249頁.

22）上野正：口腔領域の腫瘍，最新口腔外科学，東 京，1971年，医歯薬出版，45頁.

23）石川梧朗，秋吉正豊 : 口腔領域の腫瘍および腫 瘍状病変, 口腔病理学 II, 京都, 1969年, 永末 書店, 908頁.

24）清水正嗣：口腔癌の位相差顕微鏡による細胞学 的研究, 口外誌, $5: 19,1959$.

25）安藤和雄 : 干涉位相差顕微鏡による口腔領域各 種新鮮細胞の細胞学的研究, 日臨細胞誌, $8: 1$, 1969.

26）戸塚盛雄：口腔領域悪性腫瘍新鮮症例の臨床, 組織および細胞学的研究，口病誌，38：94, 1971.

27) Rangan, S. R. S. : A new human cell line $(\mathrm{FaDu})$ from a hypopharyngeal carcinoma, Cancer, $29: 117,1972$.

28) Southam, C. M. : Growth of human adenocarcinoma cells in tissue culture, Cancer, 7 : 394, 1954.

29) Cobb, J. P., Walker, D. G. : Studies on human melanoma cells in tissue culture, I. Growth characteristics and cytology, Cancer Res., 20 : 858, 1960.

30) Brown, M. M. L., Borland, R. and Milton, G. W. : Human oral malignant melanoma in cell culture, Cancer, $15: 648,1966$.

31) Kahn, L. B., Donaldson, R. C. : Multiple primary melanoma, Case report and study of tumor growth in vitro, Cancer, $26: 1162$, 1970 .

32) Korfsmeier, K. H. : Interzelluläre Verbindungen beim Plattenepithelkarzinom der men- schlichen Haut in der Gewebekultur, Experimentia, $23: 946,1967$.

33）佐藤春郎，黒木登志夫 : 実験腫瘍と組織培養, 実験腫瘍学, 東京, 1969年, 朝倉書店, 115頁.

34) Abercrombie, M., Heaysman, J. E. M. : Observations on the social behavior of cells in tissue culture, II. "Monolayering " of fibroblasts, Exptl. Cell Res., 6 : 293, 1954.

35）井坂英彦: 実験腫瘍の移植, 実験腫瘍学, 東京, 1966年，朝倉書店，76頁.

36) 石川梧朗, 秋吉正豊 : 覀性黒色腫, 口腔病理学 II，京都，1965年，永末書店，1054頁.

37) White, R. P., Tankersley, R. W. : In vitro culture of epithelial cells from normal hamster cheek pouch mucosa, Archs oral Biol., $14: 438,1969$.

38) 勝田甫, 高岡聡子 : ラッテ正常および腫瘍細胞 間の培養内相互作用, 細胞化学シンポジウム, $19: 115,1968$.

39) Chaudhry, A. P., Hampel, A. and Gorlin, R. J. : Primary malignant melanoma of the oral cavity, A review of 105 cases, Cancer, $11: 923,1958$.

40) Fielde, A. : Human tumor cells in tissue culture, Cancer, 845, 1955.

41) Herick, W., Yoneda, C.: Tissue culture of uveal melanomas, A. M. A., Arch. Opthal. $64: 406,1960$.

42) Barishank, Y. R. : Uveal melanomas, Ann. N. Y. Acad. Sci., $103:$ 478, 1963.

43) Richters, A., Sherwin, R. P.: The behavior of lymphocytes in primary explants of human lung cancer in vitro, Lab. Invest., $13: 1520$, 1964.

44) Rose, G. G. : Time-lapse cinemicrography of cells in tissue culture, Bull. Hopkins Hosp., 116 : 33, 1965.

45）山田喬 : 覀性細胞の形態, 剝離細胞診断学, 東 京, 1970年, 文光堂, 105頁.

46）太田邦夫, 増淵一正, 石束嘉男 : 悪性細胞の診 断, 細胞診の実際, 東京, 1968年, 医学書院, 175頁.

47) Fetner, R. H., Porter, E. D. : Multipolar mitosis in the KB (Eagle) human cell line and its increased frequency as a function of $250 \mathrm{kV}$ X-irradiation, Exptl. Cell Res., 37 : 429, 1965.

48) Eagle, H. : Propagation in a fluid medium of a human epidermoid carcinoma, Strain KB. (21811), Proc. Soc. Exptl Biol. Med., 89 : 362, 1955.

49) Puck, T. T., Mabcus, P. I. : Action of Xrays on mammalian cells, J. Exptl. Med., 
$103: 653,1956$

50) Wakonig-Vaartaja, R. : Search for the essential factors of carcinogenesis, Ann. N. Y. Acad. Sci, $105:$ 1, 1963.

51) Makino, S., Nakahara, H. : Cytologische Untersuchungen an Tumoren, Beobachtungen über den Mitosenablauf in lebenden Tumorzellen der ascites Sarkoma des Ratten, $Z$. Krebsforsch, $59: 298,1953$.

52）道健一：培養細胞に 対するクロモマイシン $A_{3}$ の作用, 第 2 報. Hela-S 3 細胞の核酸代謝に対 する影響，口病誌，31：65，1964.

53) Firket, H. : Cell division, cells and tissues in culture, London and New York, 1965, Academic press, p. 203.

54) Oehlert, W., Dörmer, P. und Lesch, R. : Autoradiographische Untersuchungen über die DNS-Synthese im überlebenden Tumorgewebe des Menschen, Beitr. Pathol. Anat., $128: 468,1963$.

55）関山三郎：人口腔正常上皮および悪性腫瘍組織 の in vitro の autoradiography による研究, 口病誌, $32: 90,1965$.

56) Lieb, L. M., Lisco, H.: In vitro uptake of tritiated thymidine by carcinoma of the human colon, Cancer Res., 26 : 733, 1966.
57）山城正宏：器官培養法によるヒト口腔粘膜およ び腫湟組織の研究，第 2 報, ${ }^{3} \mathrm{H}$-Thymidine お よび ${ }^{3} \mathrm{H}$-Uridine を用いた Autoradiography による研究, 口病誌, $35: 478,1968$.

58) Baserga, R.: The relationship of the cell cycle to tumor growth and control of cell division, A review, Cances Res., $25: 581$, 1965.

59) Moorhead, P. S., Defendi, V.: Asynchrony of DNA systhesis in chromosomes of human diploid cells, J. Cell Biol., 13 : 193, 1962.

60) McDonald, B. B. : Synthesis of deoxyribonucleic acid by micro- and macronucleic of Tetrahymena pyriformis, J. Cell Biol., 13 : 193, 1962.

61) Monesi, V.: Autoradiographic study of DNA synthesis and cell cycle in spermatog. onia and spermatocytes of mouse testis using tritiated thymidine, J. Cell Biol, $14: 1,1962$.

62) Stanners, C. P., Trill, J. E. : DNA synthesis in individual L-strain mouse cells, Biochem. biophys. Acta, $37:$ 406, 1960.

63）小浜源郁, 中川茂美, 臼田篤伸, 山本悦秀, 清 水正嗣，上野正 : ヒ上口蓋粘膜由来細胞の形態, 増殖，染色体に関する初代培養法による研究， 口外誌投稿中. 